\title{
NATURAL MONUMENTS IN THE ŚREM COUNTY (WIELKOPOLSKA VOIVODESHIP, POLAND)
}

\author{
Wojciech ANTKowiak, GrZegorz WiśniewsKi, Dawid Wachowiak
}

\author{
W. Antkowiak, Department of Botany, Poznań University of Life Sciences, Wojska Polskiego 71 C, 60-625 \\ Poznań, Poland, e-mail: antkowiak@au.poznan.pl
}

(Received: September 3, 2014. Accepted: November 12, 2014)

\begin{abstract}
AвSTRACT. The paper presents results of a survey of natural monuments in the Śrem county, Poland. The survey inventoried eight avenues, 30 tree clusters, six erratics, two localities of a protected plant species, and 85 trees-natural monuments. Among all trees the most numerous group comprised small-leaved limes (447 trees - 36.6\%), horse chestnuts (372 Aesculus hippocastanum - 30.4\%) as well as Acer platanoides and Quercus robur (with 99 trees each $-8.1 \%$ ). Among single trees classified as natural monuments the greatest numbers belong to Quercus robur (34 trees -40.0\%) as well as Aesculus hippocastanum and Tilia cordata (with 8 trees each $-9.4 \%$ ). In the area of the survey there are 30 clusters of trees registered as natural monument. These clusters comprise 99 trees belonging to eight species. Among them English oaks vastly predominate - 65 trees $(65.7 \%)$. Eight avenues are composed of 1038 trees belonging to seven species. The avenue with the highest number of trees is situated in Przylepki (the Brodnica comune), extending for $1.5 \mathrm{~km}$ and composed of 265 Tilia cordata specimens.

Former manor and palace parks in the Śrem county account for 33\% trees-natural monuments and $63 \%$ tree clusters.

Considerable differences were recorded in the numbers of natural monuments registered in individual decades - in the 1950's nine natural monuments were established (6.9\% total number of natural monuments), in the 1960 's - one $(0.8 \%)$, the 1970 's - one $(0.8 \%)$, the 1980 's $-41(31.3 \%)$, the 1990 's - $73(55.7 \%)$, while in the first decade of the $21^{\text {st }}$ century six natural monuments were registered $(4.6 \%)$.
\end{abstract}

KEY WORDS: natural monument, the Śrem county, survey

\section{INTRODUCTION}

The objective of nature conservation is to preserve, properly manage and restore valuable nature resources, including natural monuments. The Act of 16 April 2004 (ORDINANCE...) defines a natural monument as "single objects of animate and inanimate nature or their clusters of particular scientific, historical and commemorative value and exhibiting individual characteristics among other objects, particularly referring to old and majestic trees and shrubs of native or alien species, springs, waterfalls, karst springs, rocks, ravines, erratics, caves". Protection of natural monuments comprises various legal, planning, technical and management activities, which is connected with the application of advanced tree treatment and tending operations. Protection of natural monuments includes also amendment of legal regulations and extensive environmental awareness education activities.

Natural monuments need to be passed on to future generations. The preservation function they serve facilitates maintenance of genetic diversity, particularly in the case of old trees. Presence of ancient, majestic trees with accompanying vegetation supplies much information on the productive potential of habitats and natural development trends. It is also the remnant of natural vegetation and the old age of trees may also indicate good adaptation of a given species to existing habitat conditions (OlACZEK 1978). Majestic trees are also cultural monuments, objects of anthropological, dendrochronological or bioindication studies.

PIETRZAK (2010) stressed that a considerable obstacle in the enforcement of legal regulations concerning nature conservation in relation to trees regis- 
tered as natural monuments stems from the fact that they are not inventoried, which should be the basis for the management of this form of nature conservation in communes. As a result of insufficient documentation incorrect development orders are passed. Monitoring of illegal tree felling is also hindered, particularly in rural areas.

\section{THE STUDY AREA, MATERIAL AND METHODS}

The survey of natural monuments was conducted in the communes of the Śrem county: Brodnica, Dolsk, Książ Wielkopolski and Śrem (Fig. 1).

Investigations were conducted in the vegetation seasons of 2011 and 2012. Natural monuments were inventoried based on information collected from the
Regional Environmental Protection Directorate in Poznań and from commune offices.

Trees were inventoried by measuring their trunk circumferences at the height of $1.3 \mathrm{~m}$, accurate to 1 $\mathrm{cm}$. If a tree was located on a slope, its trunk circumference was measured from the side of the slope. Tree height was measured using a hypsometer by Suunto and recorded accurate to $0.5 \mathrm{~m}$.

Health condition of the trunk and crown was assessed in the scale proposed by PACYNIAK \& SMÓLSKI (1973):

- grade 1 (very good health condition) - completely healthy trees, with no dry damage or pest presence,

- grade 2 (good) - trees with partly dying twigs in apical parts of the crown, with the presence of plant or animal pests,

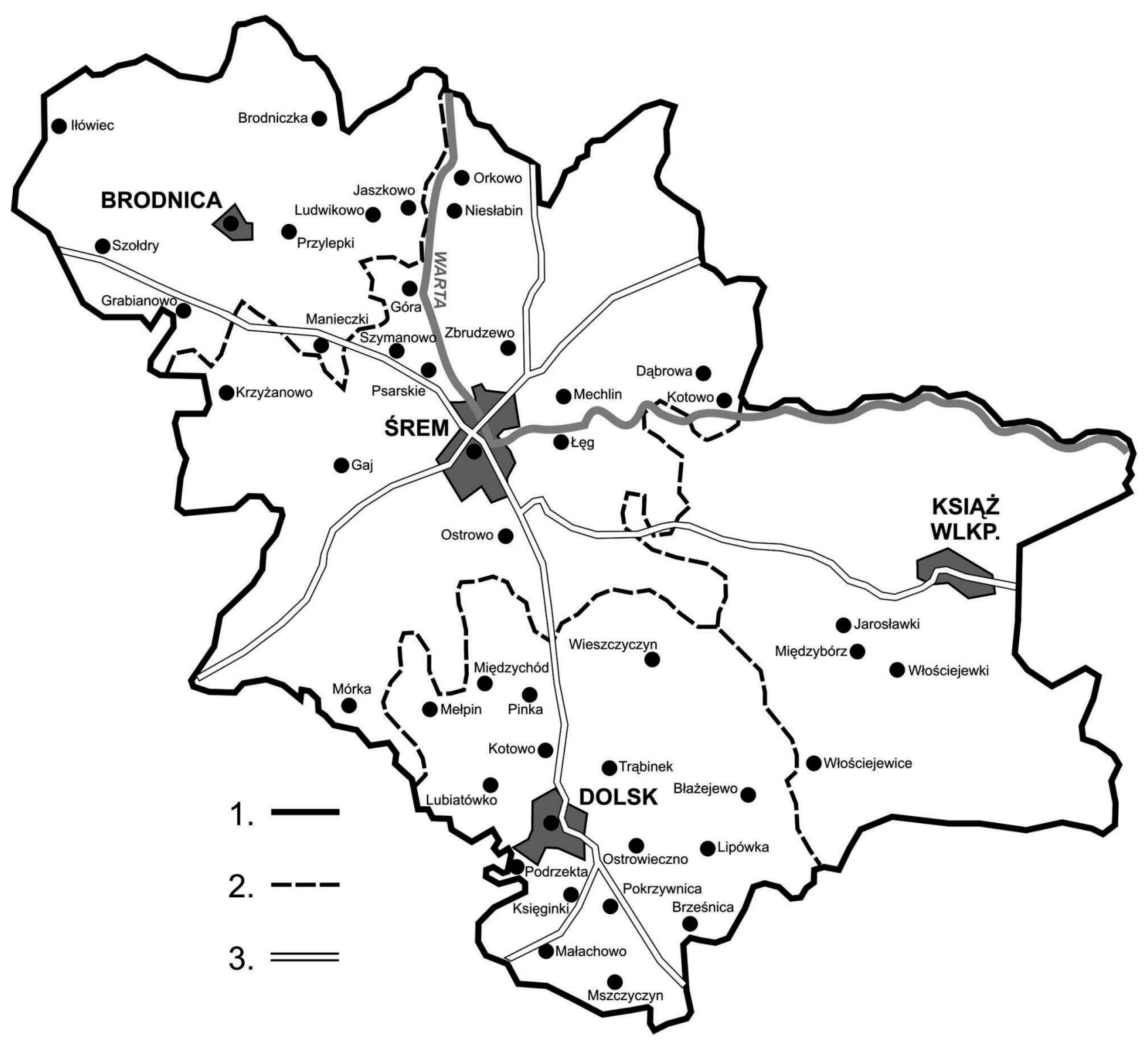

Fig. 1. Locations with natural monuments: 1 - boundaries of the Śrem county, 2 - boundaries of communes within the Śrem county, 3 - roads 
- grade 3 (medium) - trees, which have 50\% dead crown and bole or stem, trees infested by pests to a considerable degree,

- grade 4 (poor) - trees having $70 \%$ dead crown and bole or stem, considerable xylem losses,

- grade 5 (very bad) - trees having over $70 \%$ dead crown and bole or stem, with numerous holes, in which less than $25 \%$ stem circumference perform conductive functions and dead trees.

The GPS position of natural monuments was determined using the car navigation system; in the case of avenues the position was given for the beginning of the tree planting, while for tree clusters it was the location of one of the trees.

Nomenclature for trees was adopted after "Dendrology" by Seneta \& Dolatowski (2008).

In the case of erratics their circumference was measured at the widest place, height over the ground as well as length and width. The degree to which they were embedded in the subsoil as well as percentage cover by lichens or mosses were also assessed.

Tables 1 and 2 present natural monuments depending on the communes and within the communes in the order of increasing provincial register numbers and the year of monument establishment. Archival information is also given on seven natural monuments which were not found (as a result of erroneous or scarce data in the documentation).

\section{RESULTS}

In the course of the study the following natural monuments were inventoried (Tables 1 and 2):

- 85 trees (42 in the Śrem commune, 28 in the Dolsk commune, 11 in the Brodnica commune and 4 in the Książ Wielkopolski commune),

- 30 tree clusters (13 in the Dolsk commune, 9 in the Śrem commune, 7 in the Brodnica commune and 1 in the Książ Wielkopolski commune),

- 8 avenues (4 in the Brodnica commune, 3 in the Śrem commune and 1 in the Książ Wielkopolski commune),

- 6 erratics (5 in the Dolsk commune, 1 in the Książ Wielkopolski commune),

- 2 localities of Hedera helix (with one each in the Brodnica and Śrem communes).

Among the inventoried trees - natural monuments the following were most numerous: Quercus robur (34 trees - 40.0\%), Aesculus hippocastanum and Tilia cordata (with 8 trees each $-9.4 \%$ ), Fraxinus excelsior (7 ash trees $-8.2 \%$ ) and Alnus glutinosa (6 alders $-7.1 \%)$. The other 22 natural monuments belong to 12 species (25.9\% all trees - natural monuments). They include: Acer platanoides, Fagus sylvatica, Ginkgo biloba, Pinus nigra, P. sylvestris, Platanus $\times$ hispanica Acerifolia, Populus nigra, Salix alba, Thuja occidentalis, Th. orientalis, Tilia platyphyllos and Ulmus laevis.
In the study area there are 30 tree clusters registered as natural monuments. They are composed of 99 trees belonging to eight species. English oaks definitely predominate here -65 trees $(65.7 \%)$.

The eight avenues comprise 1038 trees belonging to seven species. The stately avenue in Przylepki (the Brodnica commune), extending over a distance of 1.5 $\mathrm{km}$, composed of 265 Tilia cordata specimens.

A total of 1222 trees of 21 species (among all natural monuments) were inventoried: 447 trees of Tilia cordata (36.6\%), 372 Aesculus hippocastanum (30.4\%), with 99 each $(8.1 \%)$ of Acer platanoides and Quercus robur, 98 Picea abies (8.0\%), 34 Platanus $\times$ hispanica (2.8\%), 28 Fraxinus excelsior (2.3\%), 9 Ulmus laevis, with six trees each of Acer campestre, Alnus glutinosa and Taxus baccata, 4 Acer pseudoplatanus, 3 Thuja occidentalis, with two each of Fagus sylvatica, Populus nigra and Tilia platyphyllos, with one each of Ginkgo biloba, Pinus nigra, P. sylvestris, Salix alba and Thuja orientalis. Among them gymnosperm trees accounted for $9.1 \%$ all inventoried trees.

The most majestic trees in the study area (among all categories of natural monuments) are:

- English oaks Quercus robur - 21 of which had circumferences of 5-6 m, while five oaks had circumferences of $6.25 \mathrm{~m}$ (Table 1, no. 402, the Śrem commune), $6.39 \mathrm{~m}$ (Table 1, no. 14, the Brodnica commune), $6.60 \mathrm{~m}$ (Table 1 , no. 345 , the Brodnica commune and Table 2, no. 771, the Dolsk commune) and 6.70 (Table 1, no. 414, the Śrem commune). One oak had a circumference of $7.0 \mathrm{~m}$ (Table 2, no. 94, the Dolsk commune), one 7.30 m (Table 2, no. 533, the Dolsk commune), while two the thickest - circumferences of $8.04 \mathrm{~m}$ (Table 1, no. 416, the Dolsk commune) and $8.20 \mathrm{~m}$ (Table 1, no. 769, the Brodnica commune);

- Small-leaved lime Tilia cordata - one had a circumference of $6.10 \mathrm{~m}$ (Table 1, no. 774, the Dolsk commune);

- European white elm Ulmus laevis from Orkowo with a circumference of $4.15 \mathrm{~m}$ (Table 1, no. 33, the Śrem commune);

- two European ashes Fraxinus excelsior from the former manor park in Brodnica with circumferences of 6.0 and $5.7 \mathrm{~m}$ (Table 1, no. 661; Table 2, no. 191);

- five horse chestnuts Aesculus hippocastanum with circumferences of 4.0-4.5 m (Table 1, nos. 13, 26, 28-30);

- two field maples Acer campestre from the former manor park in Wieszczyczyn, with circumferences of $3.10 \mathrm{~m}$ (Table 2, no. 528, the Dolsk commune);

- London planetrees Platanus Xhispanica 'Acerifolia' - two had circumferences of 5.1 and $5.3 \mathrm{~m}$, two of 6.3 and $6.4 \mathrm{~m}$ (Table 2; no. 380, the Śrem commune; no. 706, the Brodnica commune);

- Black poplars Populus nigra from Ostrów (circumference $5.12 \mathrm{~m}$, Table 1, no. 37, the Śrem com- 


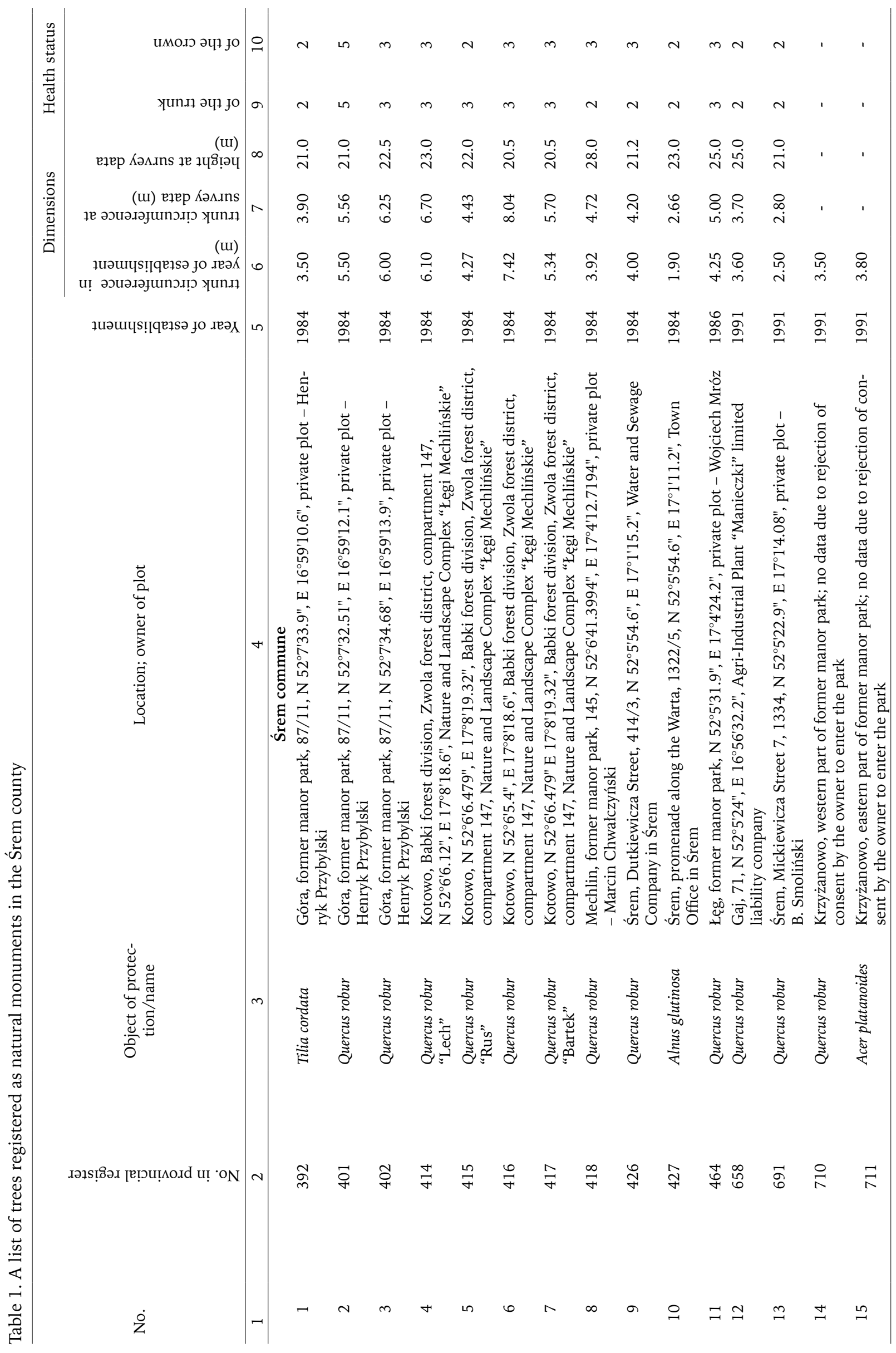




\begin{tabular}{|c|c|c|c|c|c|c|c|c|c|c|c|c|c|c|}
\hline 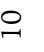 & $m$ & $\sim$ & $N$ & N & N & N & $m$ & $m$ & $\sim$ & N & - & $m$ & - & $r$ \\
\hline & $\sim$ & $\sim$ & N & N & $\sim$ & N & N & $\sim$ & $\sim$ & $m$ & $\neg$ & $n$ & - & + \\
\hline & $\stackrel{\circ}{\stackrel{+}{\sim}}$ & 䓍 & 임 & $\stackrel{\circ}{\vec{\sim}}$ & $\stackrel{\circ}{\vec{\sim}}$ & $\begin{array}{l}\stackrel{\leftrightarrow}{\vec{\lambda}} \\
\text {. }\end{array}$ & $\begin{array}{l}\text { ㅁ․ } \\
\text { मे }\end{array}$ & $\stackrel{\circ}{\stackrel{\leftrightarrow}{\sim}}$ & $\begin{array}{l}0 \\
\dot{i}\end{array}$ & $\begin{array}{l}\circ \\
\text { id }\end{array}$ & $\stackrel{\stackrel{n}{?}}{\stackrel{2}{n}}$ & $\stackrel{\circ}{\text { in }}$ & $\stackrel{\circ}{\stackrel{\vec{\lambda}}{ }}$ & $\stackrel{\llcorner}{\underset{+}{+}}$ \\
\hline & 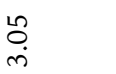 & $\begin{array}{l}\stackrel{0}{0} \\
\stackrel{N}{N}\end{array}$ & $\begin{array}{l}\stackrel{0}{\sim} \\
\dot{n}\end{array}$ & 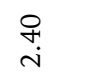 & $\begin{array}{l}\stackrel{n}{n} \\
\stackrel{n}{N}\end{array}$ & $\stackrel{m}{\sim}$ & $\stackrel{n}{\stackrel{n}{m}}$ & 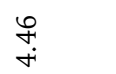 & 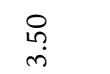 & $\begin{array}{l}\stackrel{0}{m} \\
m\end{array}$ & 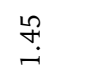 & $\begin{array}{l}\infty \\
\infty \\
\dot{m}\end{array}$ & $\begin{array}{l}\stackrel{\infty}{\infty} \\
\stackrel{N}{i}\end{array}$ & $\begin{array}{l}\stackrel{\circ}{\sim} \\
\dot{m}\end{array}$ \\
\hline & $\underset{\substack{f \\
i}}{ }$ & 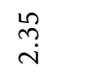 & 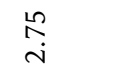 & 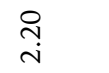 & $\begin{array}{l}\stackrel{0}{N} \\
\text {. }\end{array}$ & $\underset{\stackrel{i}{i}}{\stackrel{O}{1}}$ & $\stackrel{\vec{n}}{\mathrm{~N}}$ & 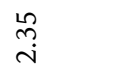 & 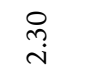 & $\begin{array}{l}\stackrel{L}{\infty} \\
\stackrel{i}{i}\end{array}$ & 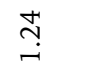 & $\begin{array}{l}8 \\
\dot{m}\end{array}$ & $\begin{array}{l}\stackrel{\theta}{0} \\
i\end{array}$ & 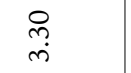 \\
\hline & న్ & જે & Љ & مి & & & & ڤે & ๙ু & مి & مू & Љু & ڤે & જે \\
\hline & 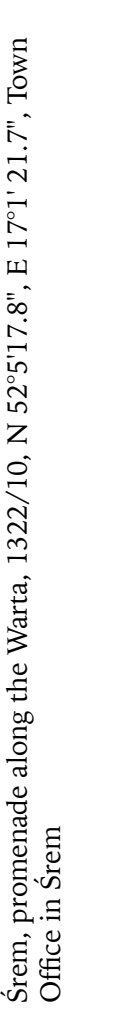 & 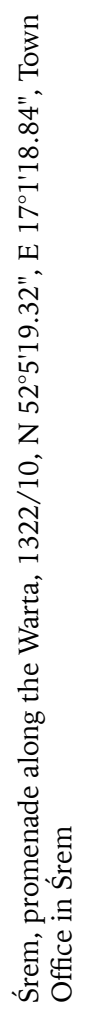 & 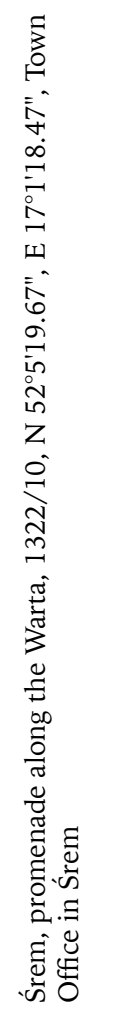 & 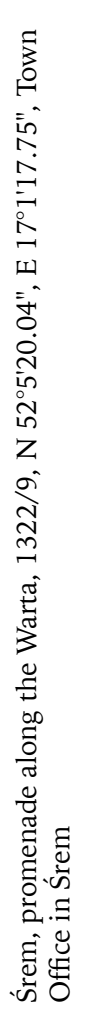 & 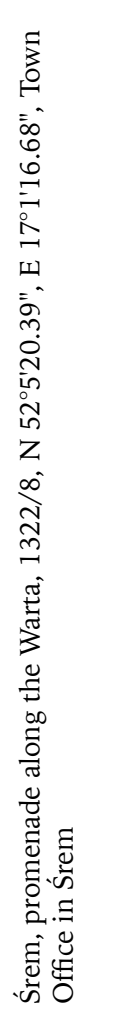 & 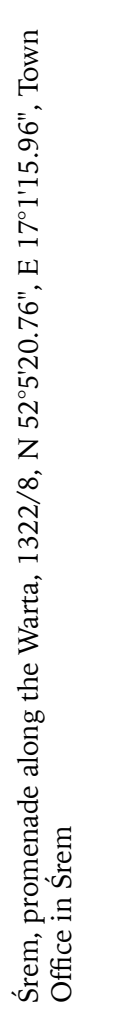 & 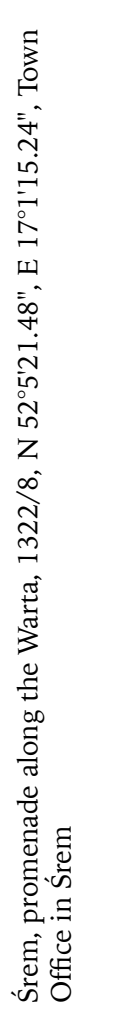 & 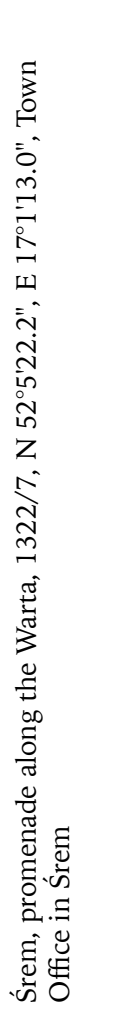 & 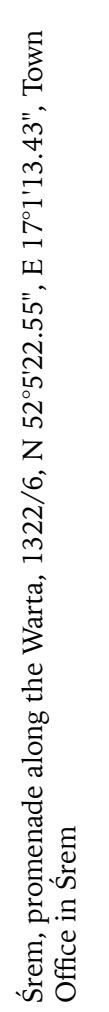 & 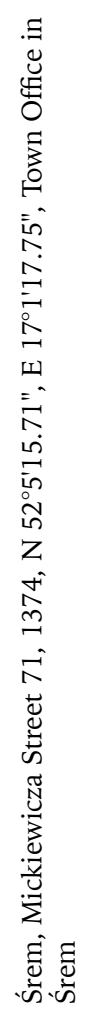 & 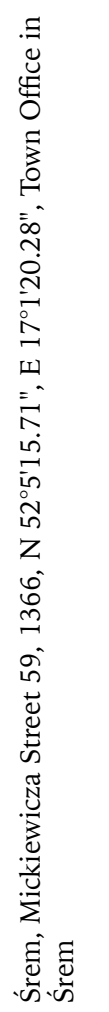 & 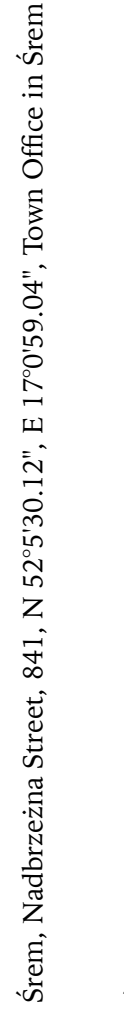 & 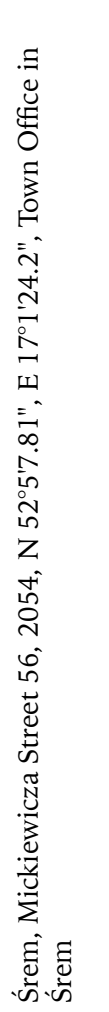 & 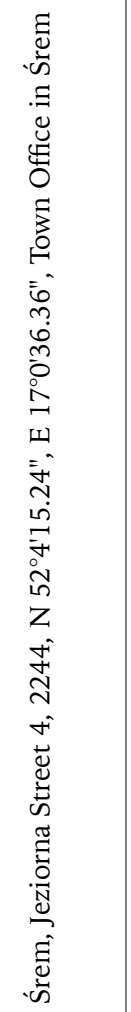 \\
\hline & 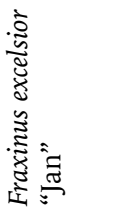 & 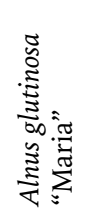 & 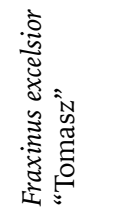 & 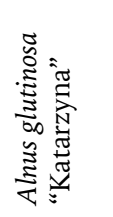 & 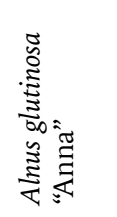 & 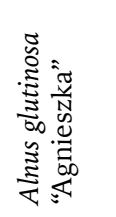 & 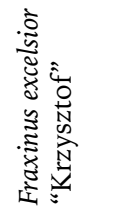 & 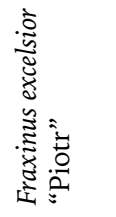 & 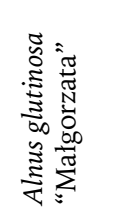 & 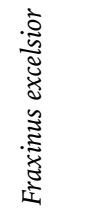 & 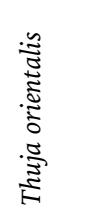 & 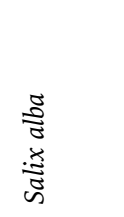 & 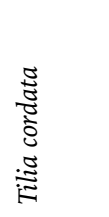 & 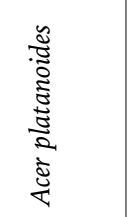 \\
\hline & 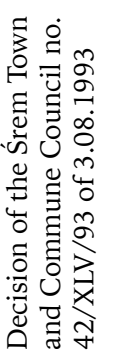 & 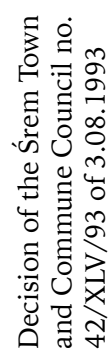 & 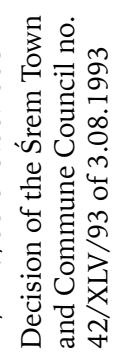 & 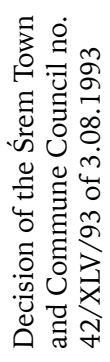 & 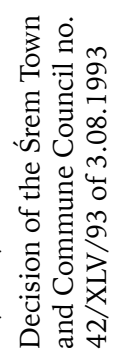 & 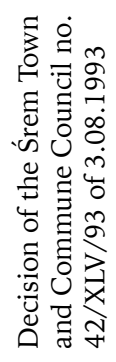 & 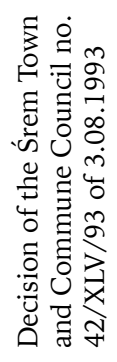 & 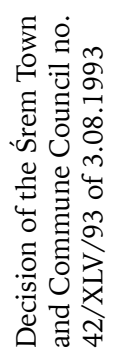 & 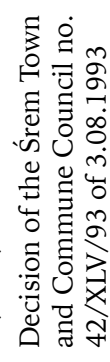 & 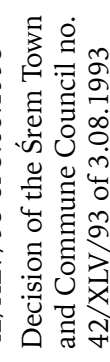 & 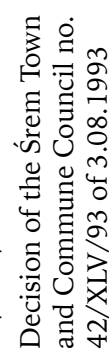 & 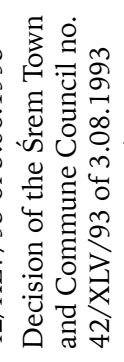 & 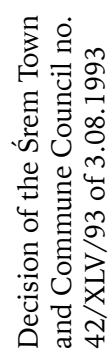 & 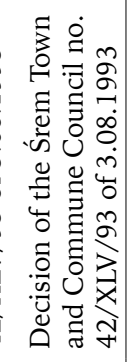 \\
\hline & $c$ & 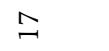 & $\stackrel{\infty}{\sim}$ & $\stackrel{g}{\rightarrow}$ & ㄱ. & $\vec{d}$ & ป & $\stackrel{\sim}{\sim}$ & $\stackrel{+}{\sim}$ & $\stackrel{\sim 2}{\sim}$ & $\stackrel{\bullet}{\sim}$ & $\hat{\imath}$ & $\stackrel{\infty}{\sim}$ & ని \\
\hline
\end{tabular}




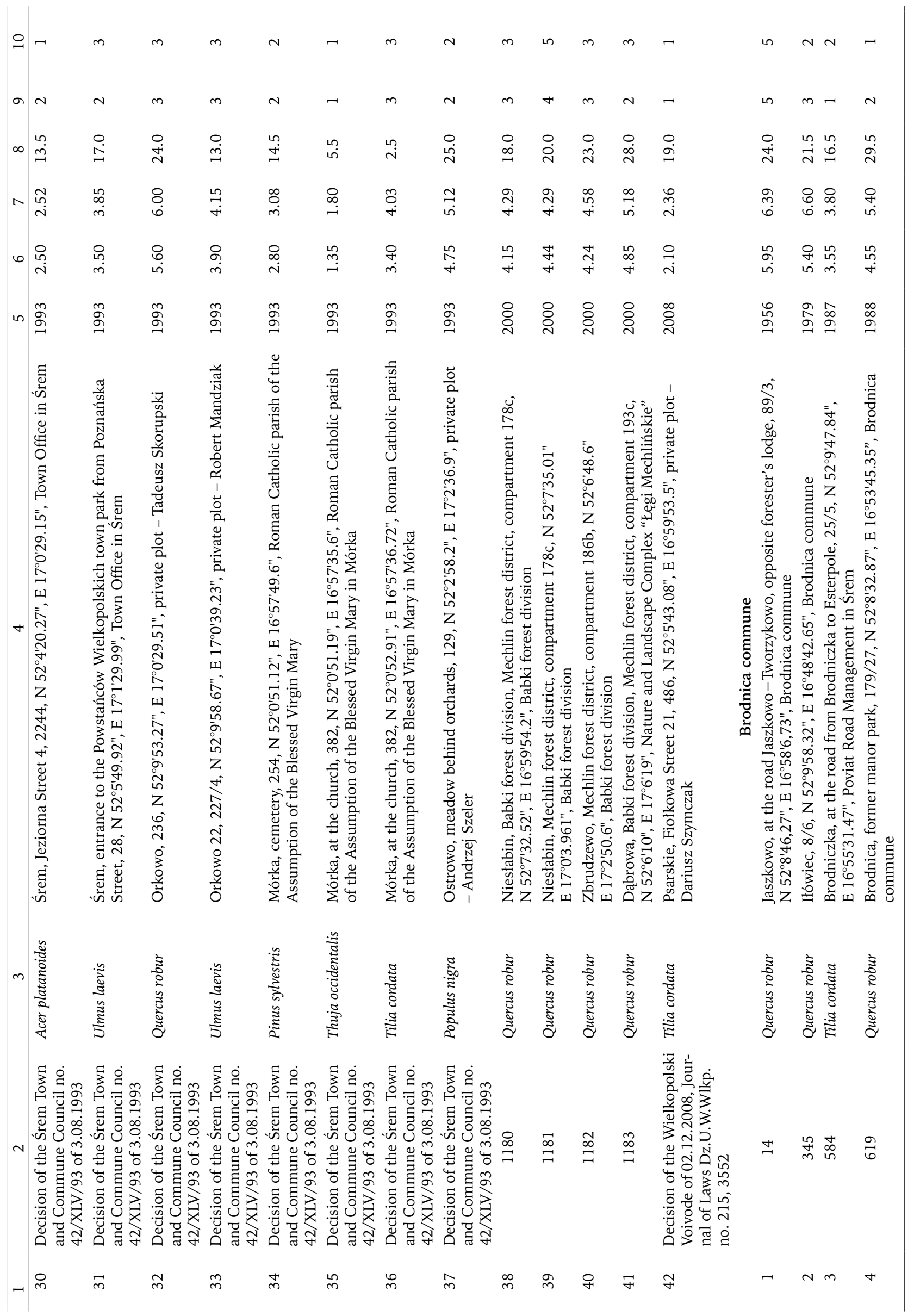




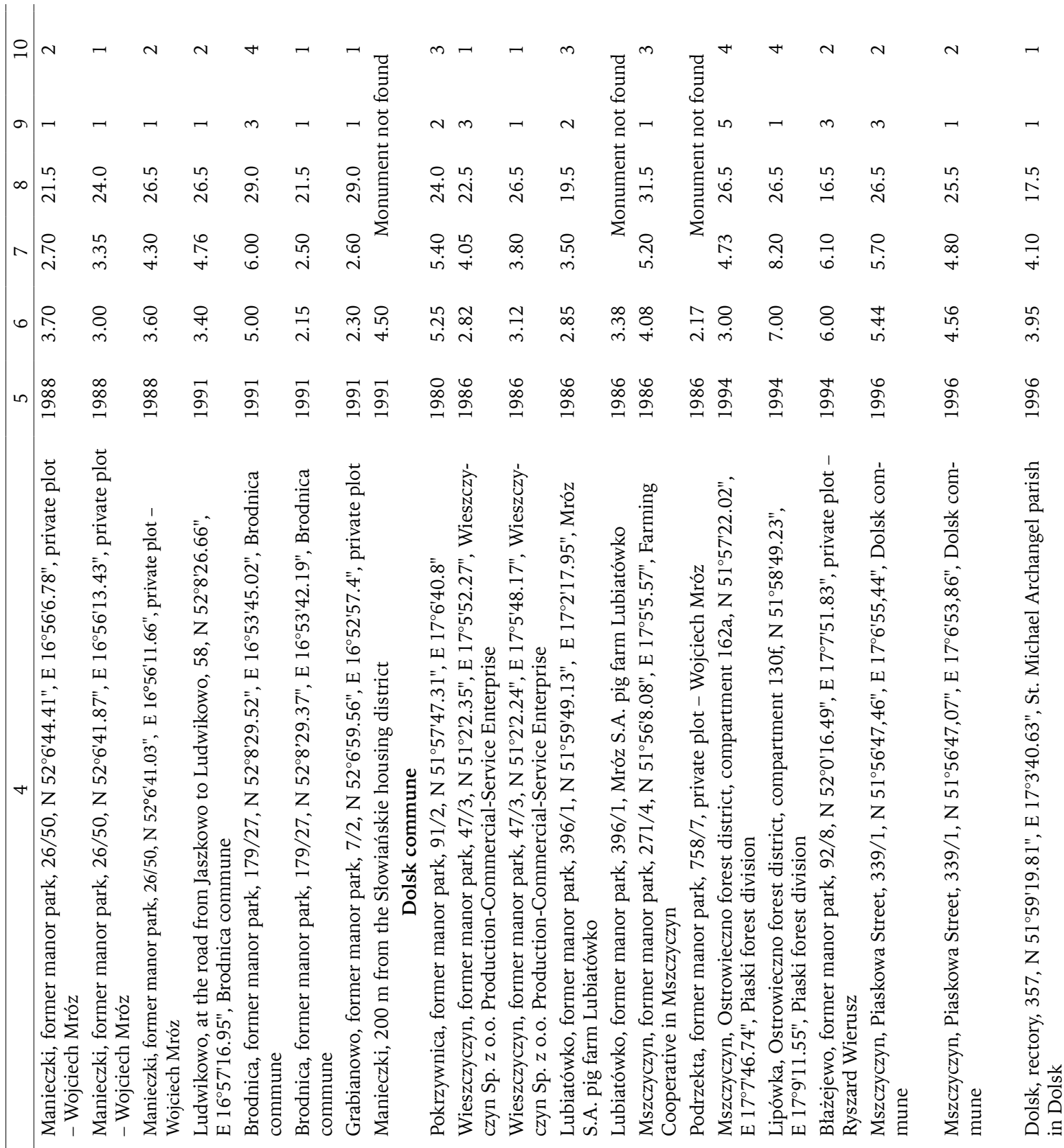

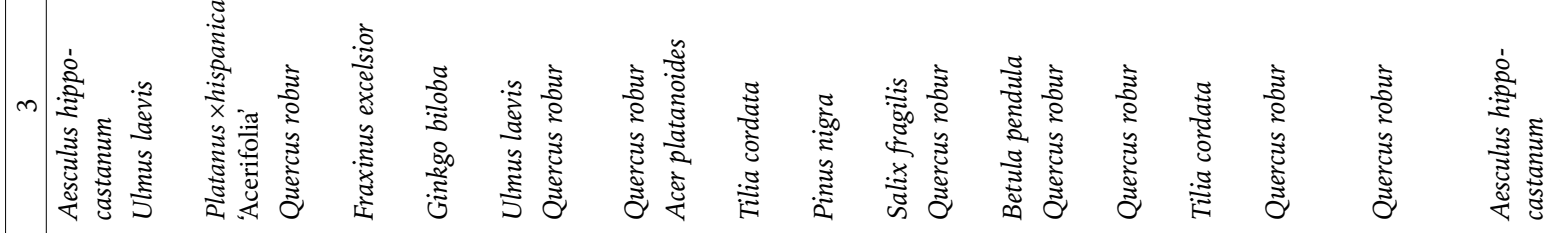

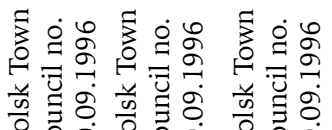

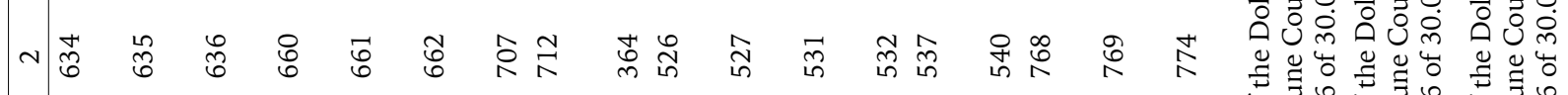

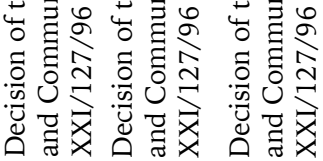

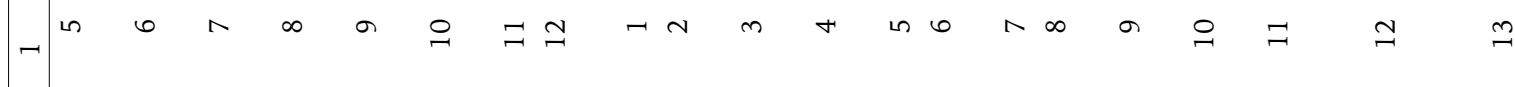




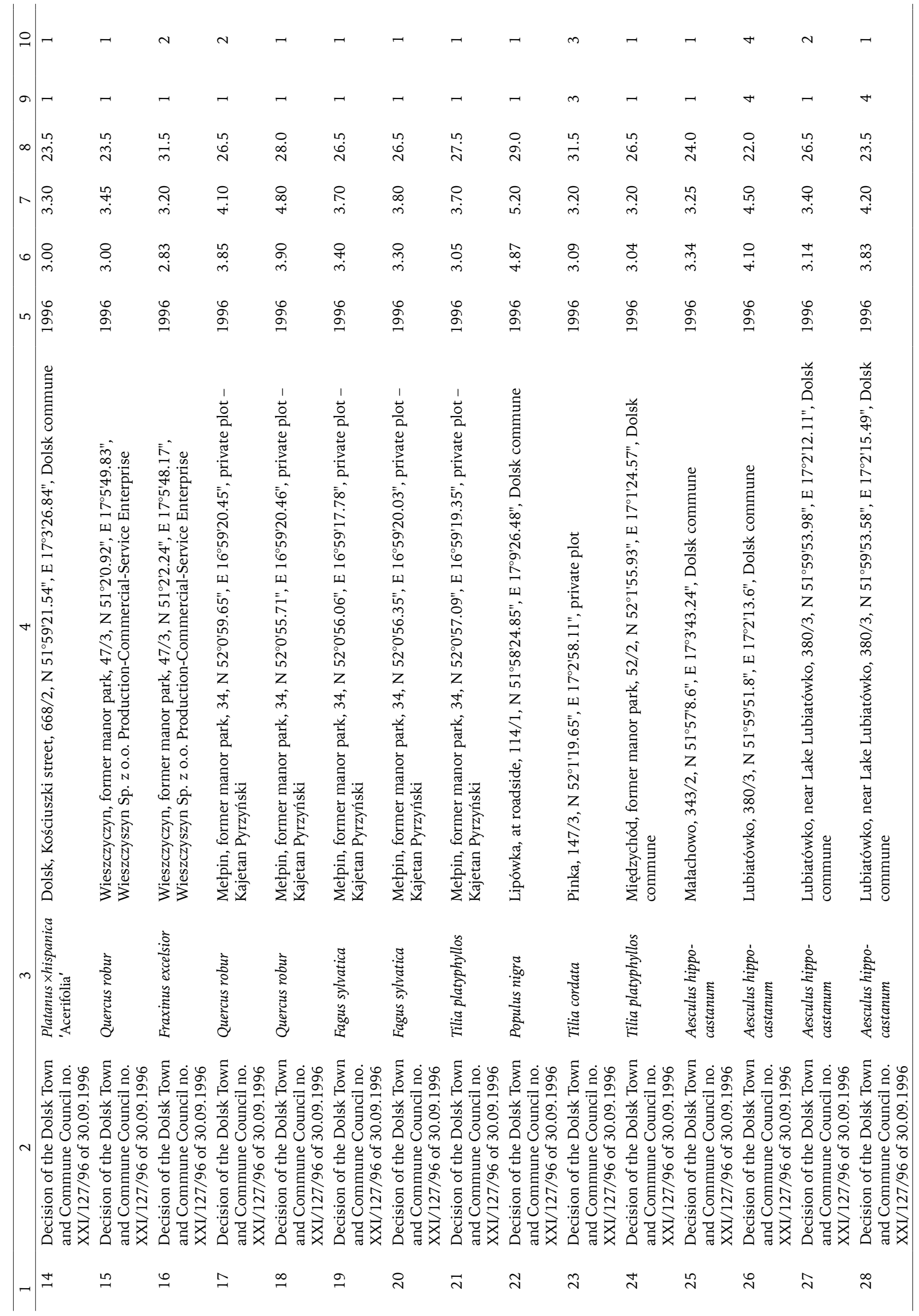



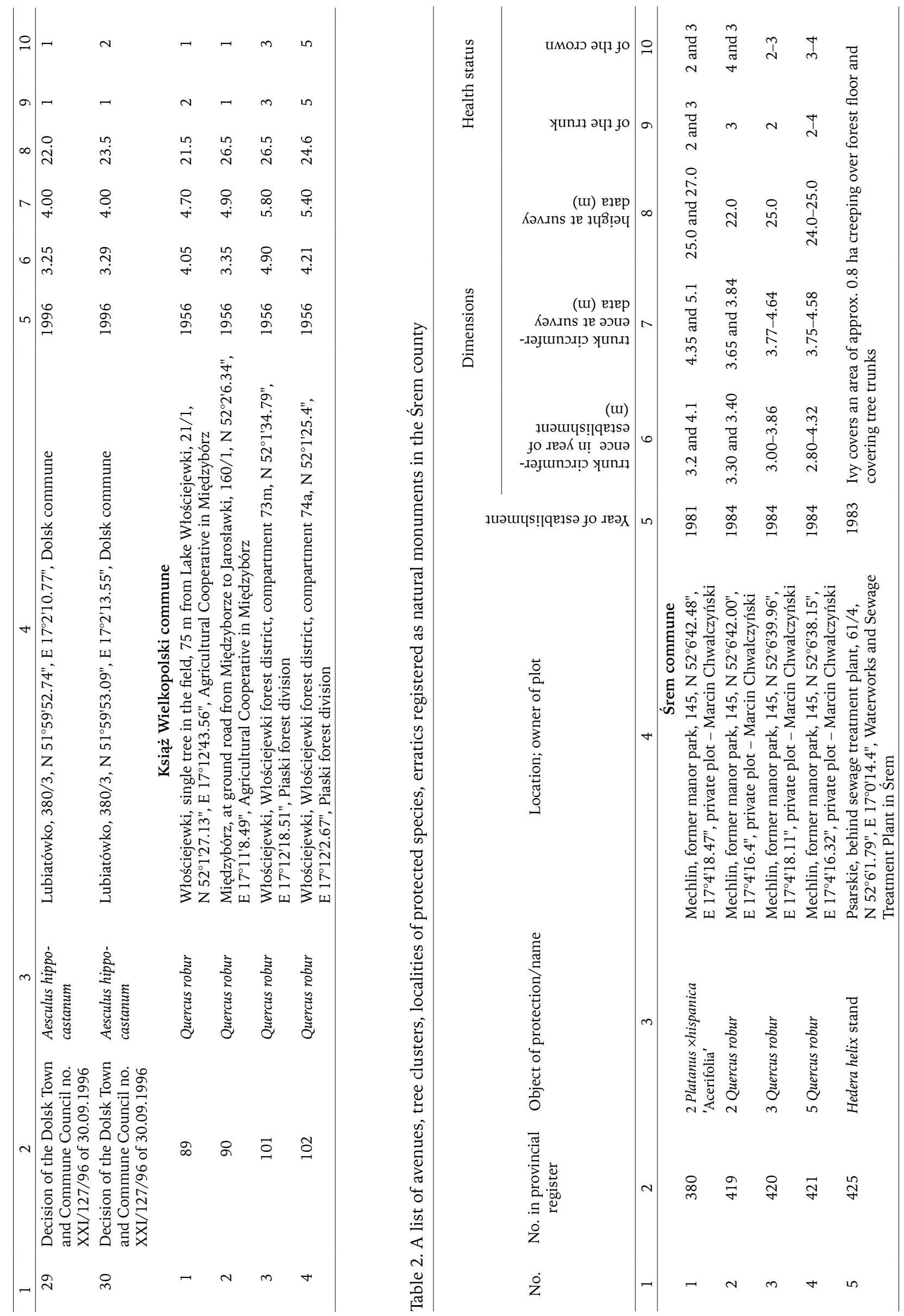


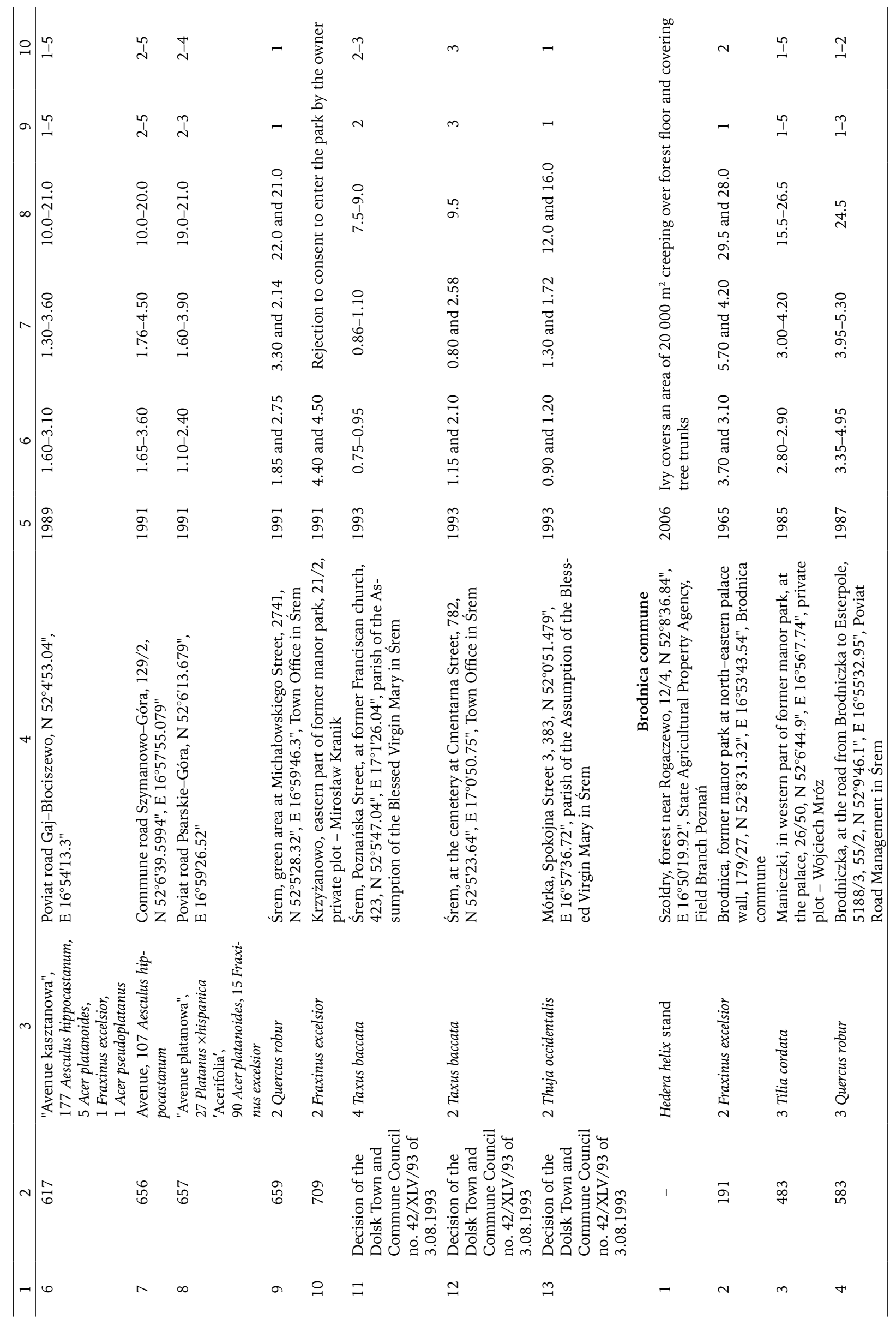




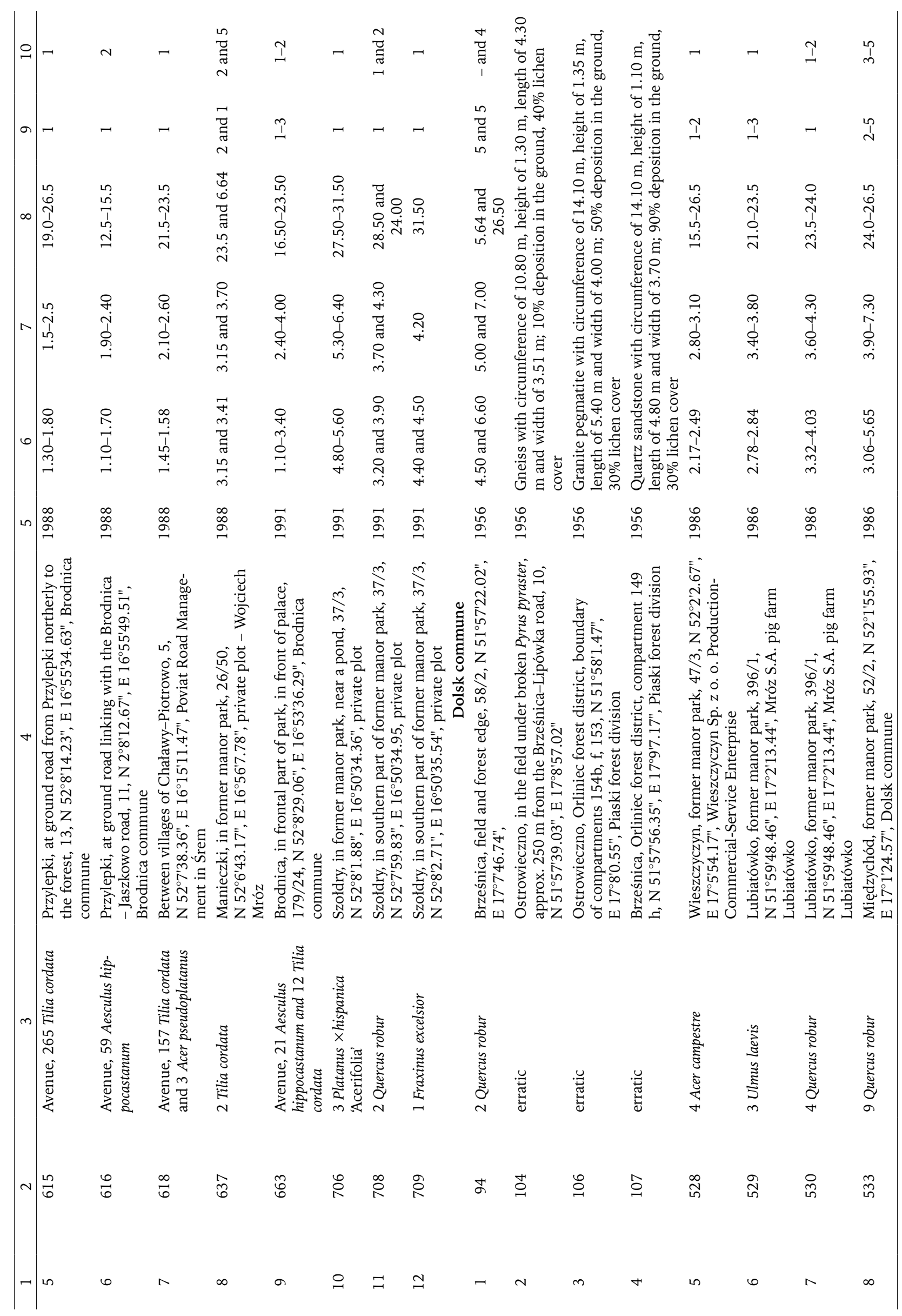




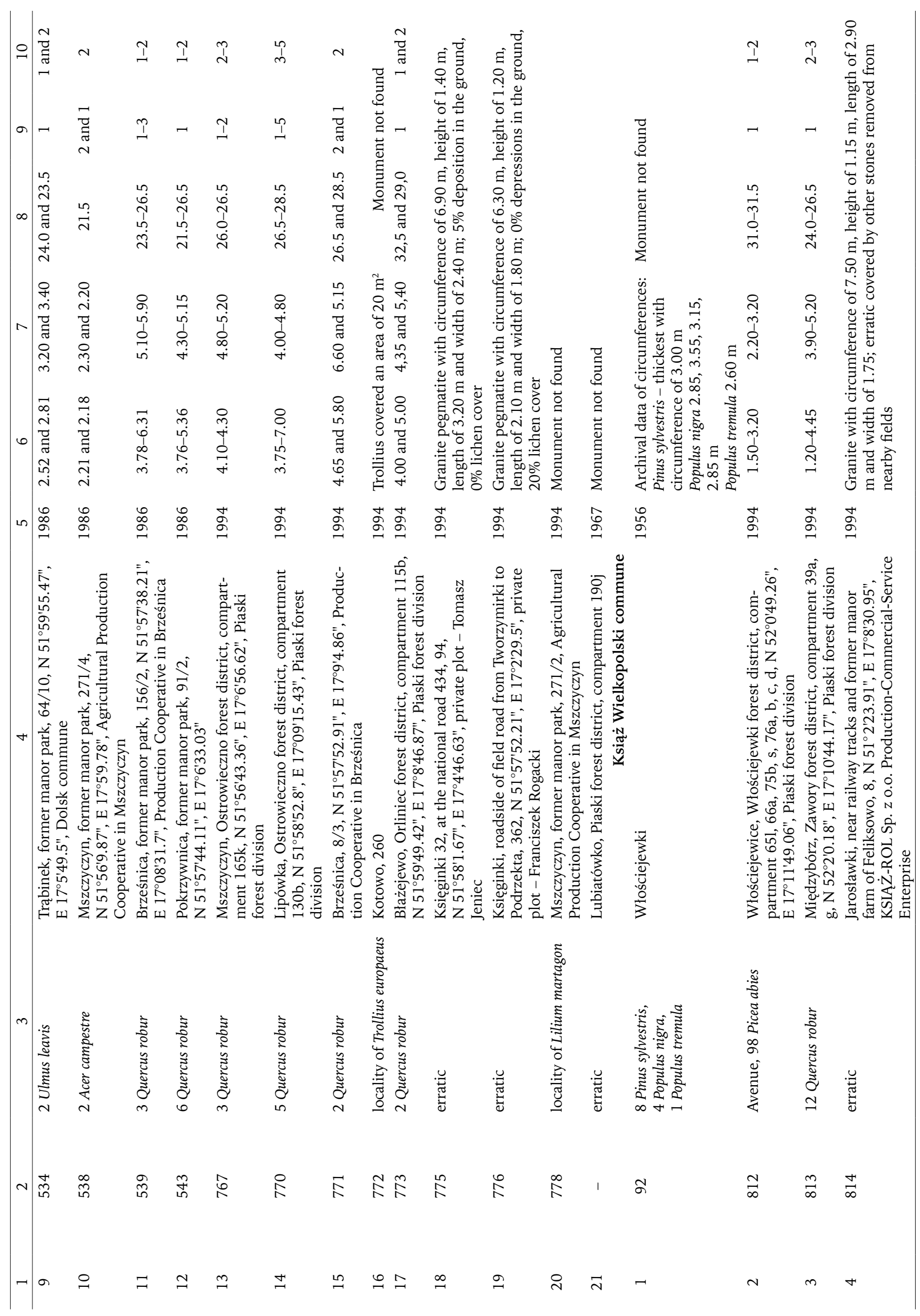


mune) and from Lipówka (circumference $5.20 \mathrm{~m}$, Table 1, no. 22, the Dolsk commune);

- a Norway maple Acer platanoides from Wieszczyczyn with a circumference of $4.05 \mathrm{~m}$ (Table 1, no. 526, the Dolsk commune);

- a Maidenhair tree Ginkgo biloba from Brodnica, with a circumference of $2.5 \mathrm{~m}$ (Table 1, no. 662, the Brodnica commune).

In former manor and palace parks in the Śrem county there are 28 (33\%) trees-natural monuments. Marked differences were found between individual communes: in the Śrem commune in parks a total of $17 \%$ trees-natural monuments were registered, in the $64 \%$, in the Dolsk commune $50 \%$, while in the Książ Wielkopolski commune there were no natural monuments in parks. Moreover, the natural monument status was given to $18(21 \%)$ trees growing in forests, one growing in a Catholic cemetery, two near a church, 19 (22\%) in Śrem, while 17 (20\%) in other towns or in the roadside or fields.

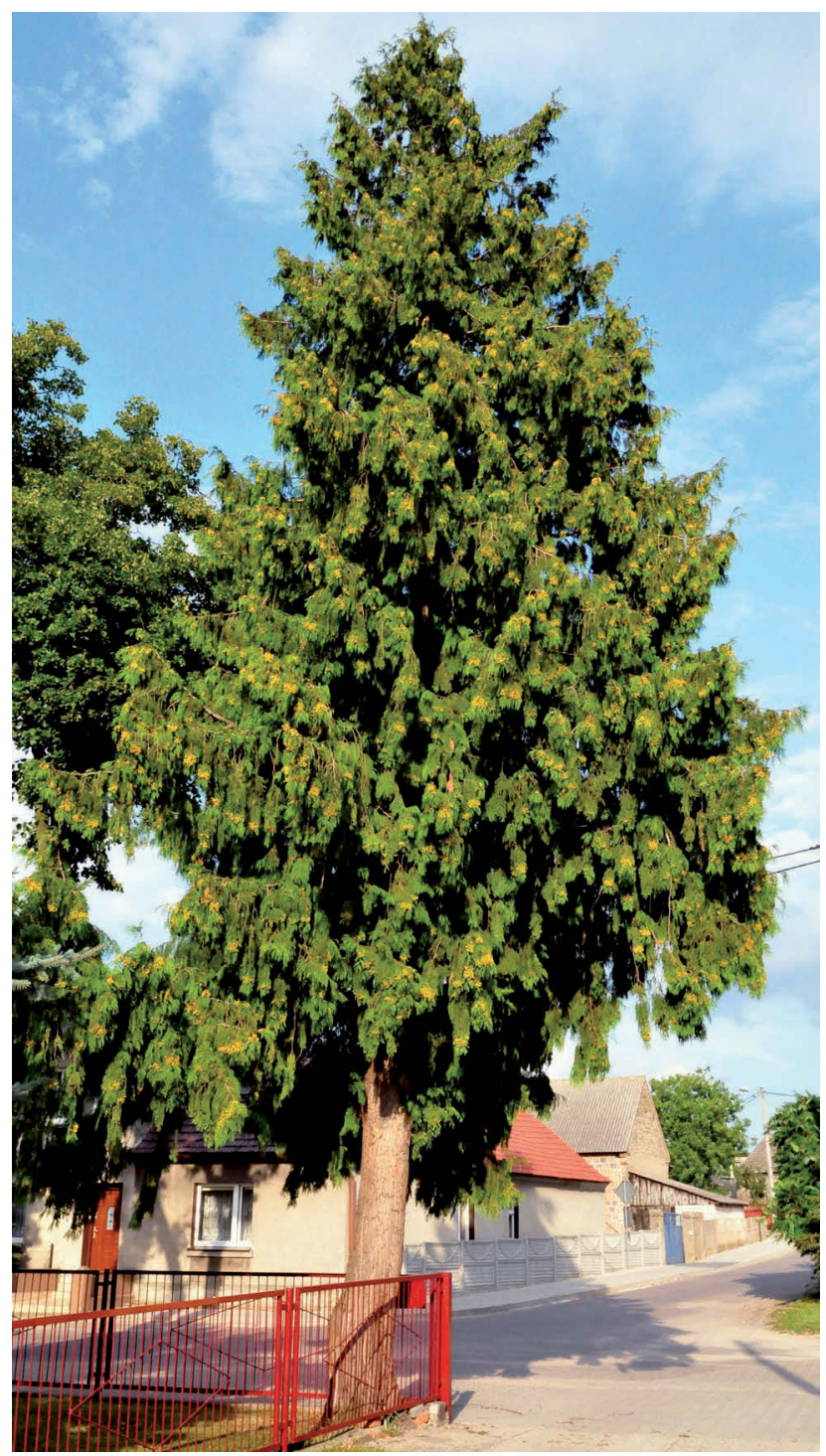

Former manor and palace parks comprise 19 $(63 \%)$ tree clusters, four $(13 \%)$ in forests, three $(10 \%)$ in church plots and four $(13 \%)$ in other locations.

Among the 131 inventoried natural monuments in the study area 46 (35\%) were established by the local government bodies (26 in the Śrem commune and 20 in the Dolsk commune). The other were established on the power of the ordinance of the Provincial Governor [Wojewoda] or a decision by the Provincial National Council.

The manner of registration of natural monuments is not always precise and they are not always adequately marked. Not all established monuments have been labelled with a plaque with the inscription "NATURAL MONUMENT". Among 85 trees-natural monuments such plaques were placed on 60 trees.

Considerable differences were observed in the numbers of established natural monuments in individual decades - in the 1950's nine natural monu-

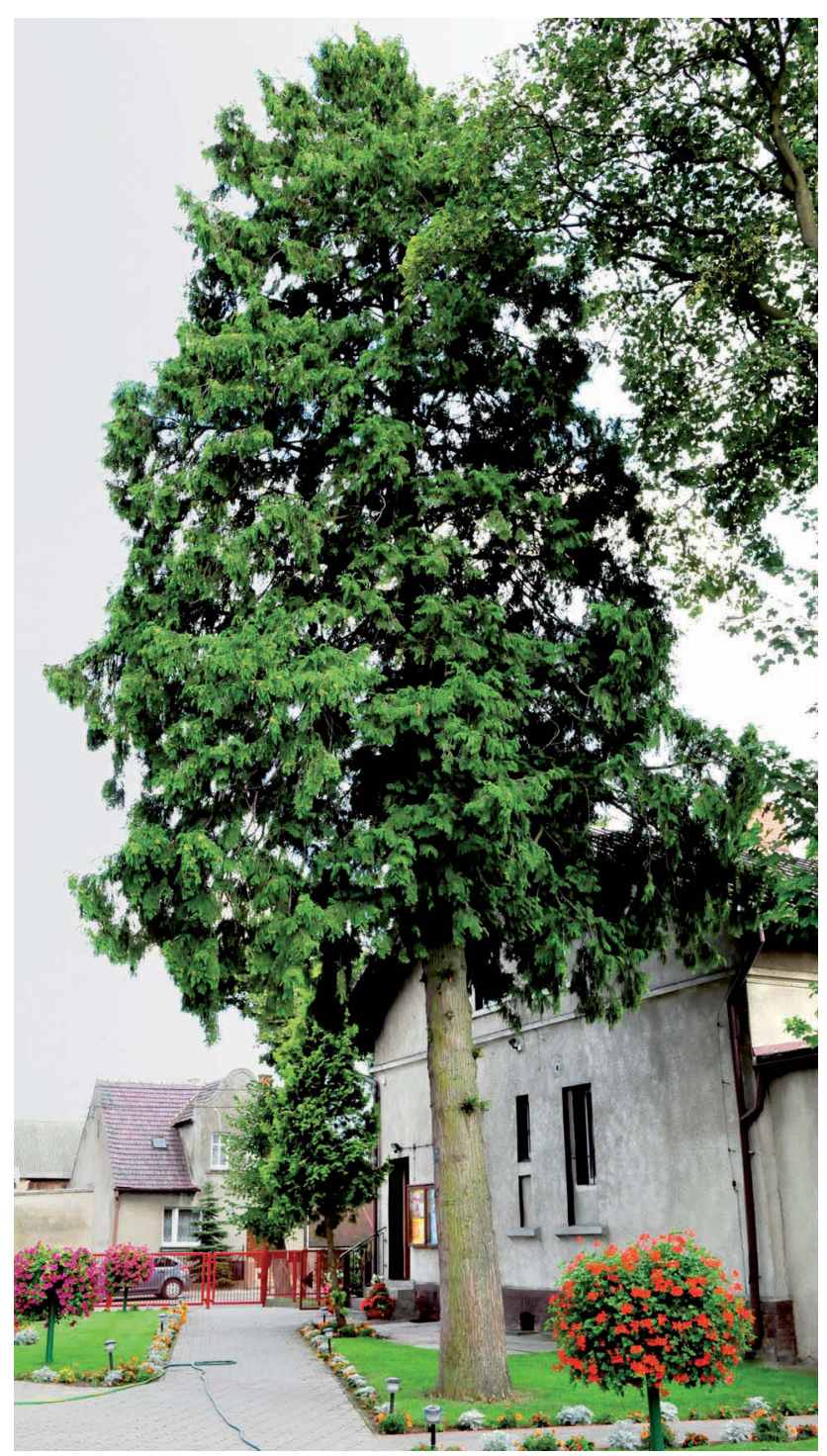

Phot. 1. Thuja occidentalis growing at the church in Mórka (tab. 2, no. 13, the Śrem commune); photo M. Krajewski 


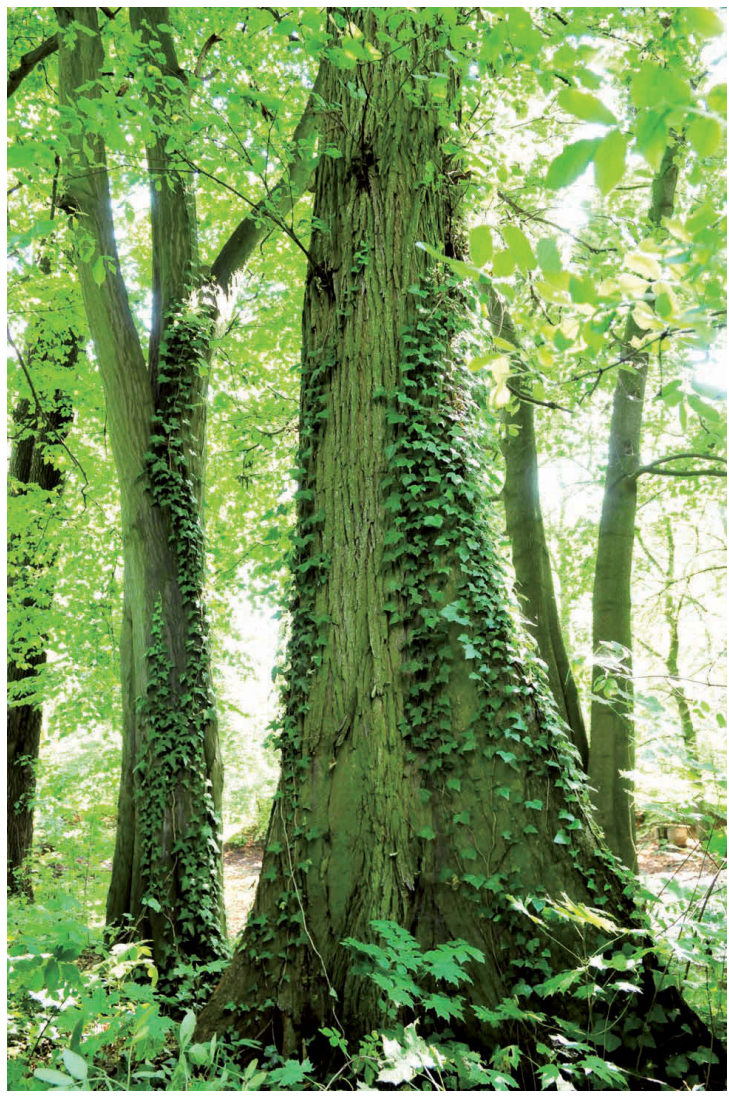

Phot. 2. Ulmus laevis from the former manor park in Manieczki (Table 1, no. 635, the Brodnica commune); photo M. Krajewski

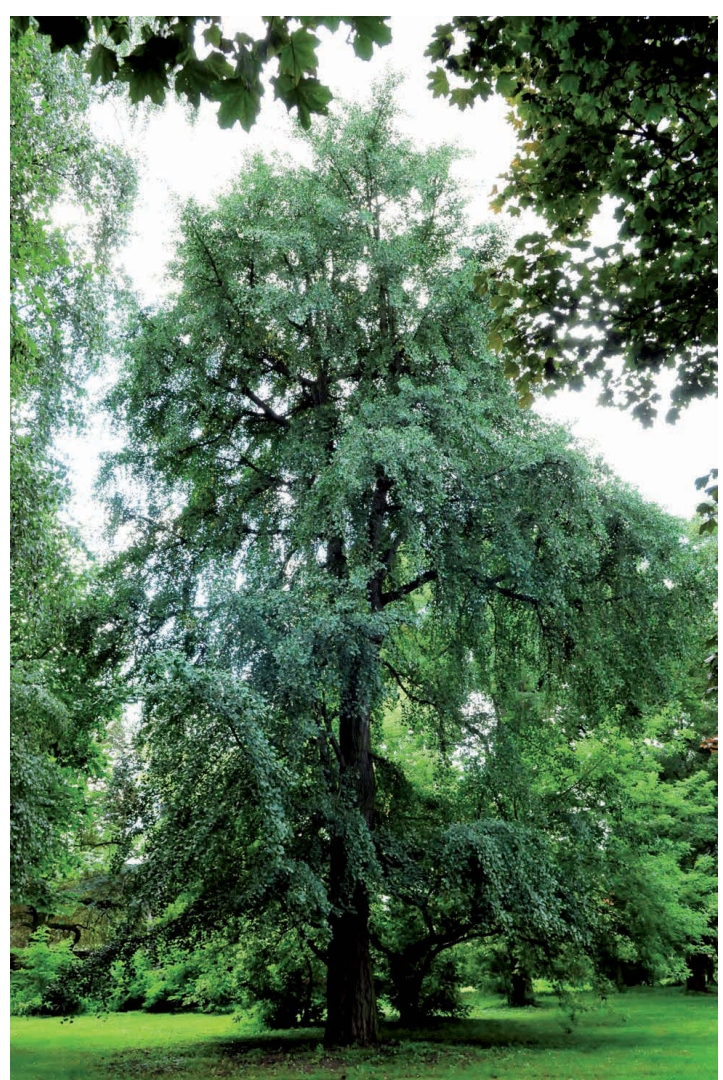

Phot. 4. Ginkgo biloba from the park in Brodnica (Table 1, no. 662 , the Brodnica commune); photo M. Krajewski

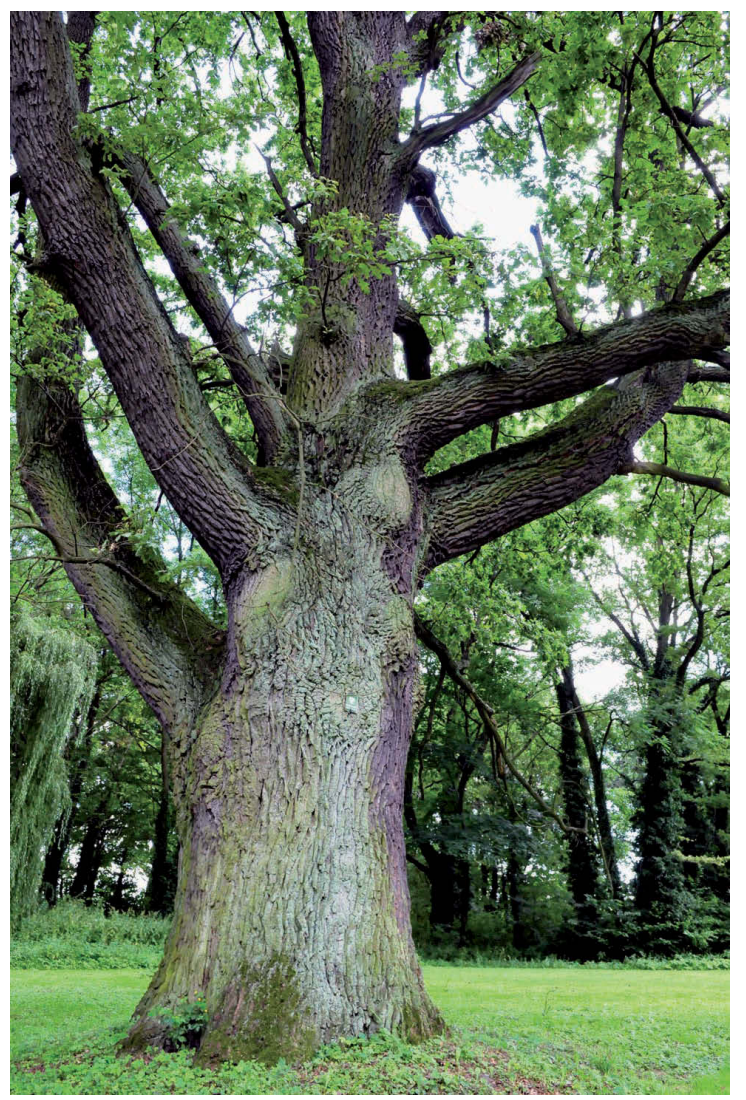

Phot. 3. Quercus robur from Brodnica (Table 1, no. 619, the Brodnica commune); photo M. Krajewski

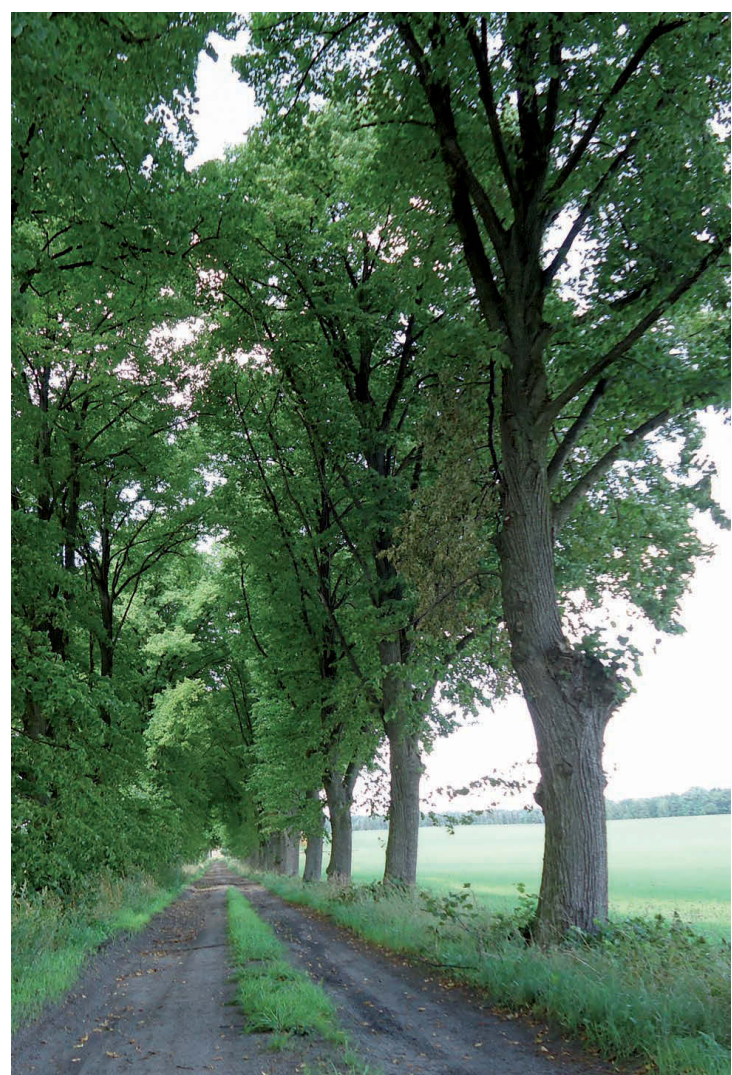

Phot. 5. The lime avenue in Przylepki (Table 2, no. 615, the Brodnica commune); photo M. Krajewski 


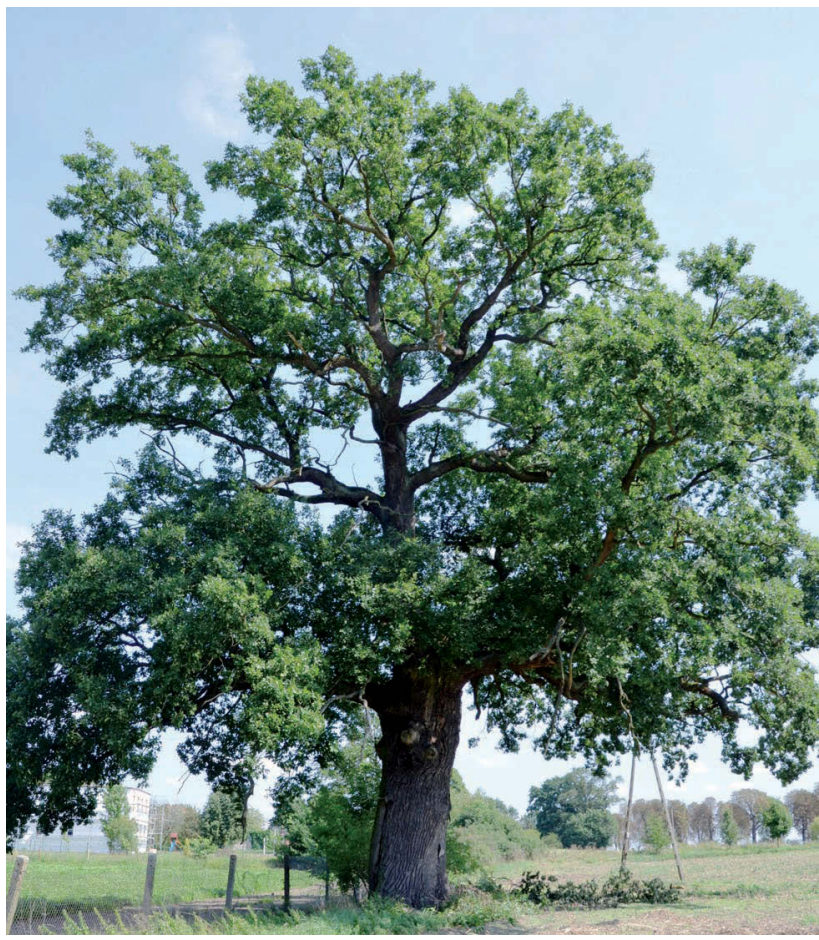

Phot. 6. Quercus robur from Iłówiec (Table 1, no. 345, the Brodnica commune); photo W. Antkowiak

ments were established $(6.9 \%$ total number of natural monuments), in the 1960's - one (0.8\%), the 1970's - one $(0.8 \%)$, the 1980 's $-41(31.3 \%)$, the 1990 's -73 $(55.7 \%)$, while in the first decade of the $21^{\text {st }}$ century six natural monuments were established (4.6\%).

We need to mention here several changes in the numbers of natural monuments:

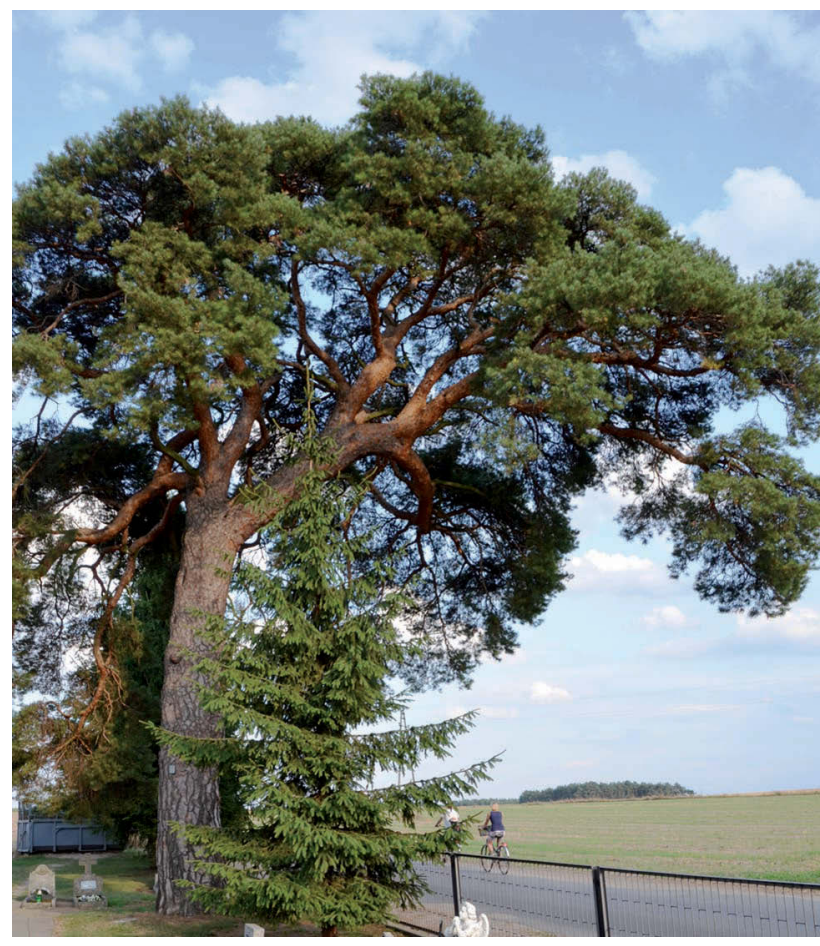

Phot. 7. Scots pine growing in the cemetery in Mórka (Table 1, no. 34, the Śrem commune); photo W. Antkowiak

- the tree cluster monument no. 709 established in 1991 (the Brodnica commune, Table 2) comprised two Fraxinus excelsior trees; only one of the two European ashes is left;

- the tree cluster no. 94 (the Dolsk commune, Table 2 ) is composed of two Quercus robur trees; at the

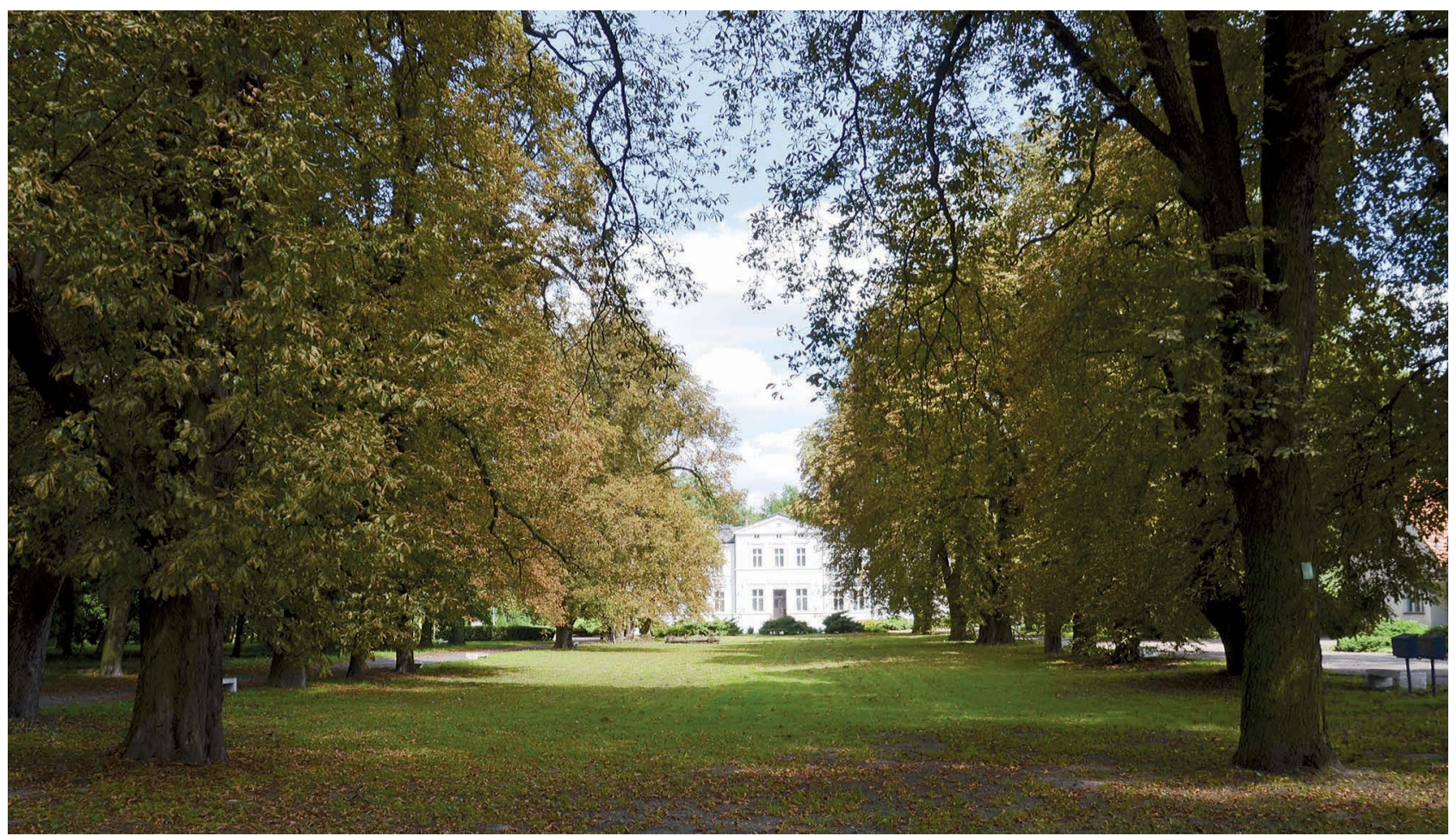

Phot. 8. The avenue in front of the palace in Brodnica (Table 2, no. 663, the Brodnica commune); photo W. Antkowiak 


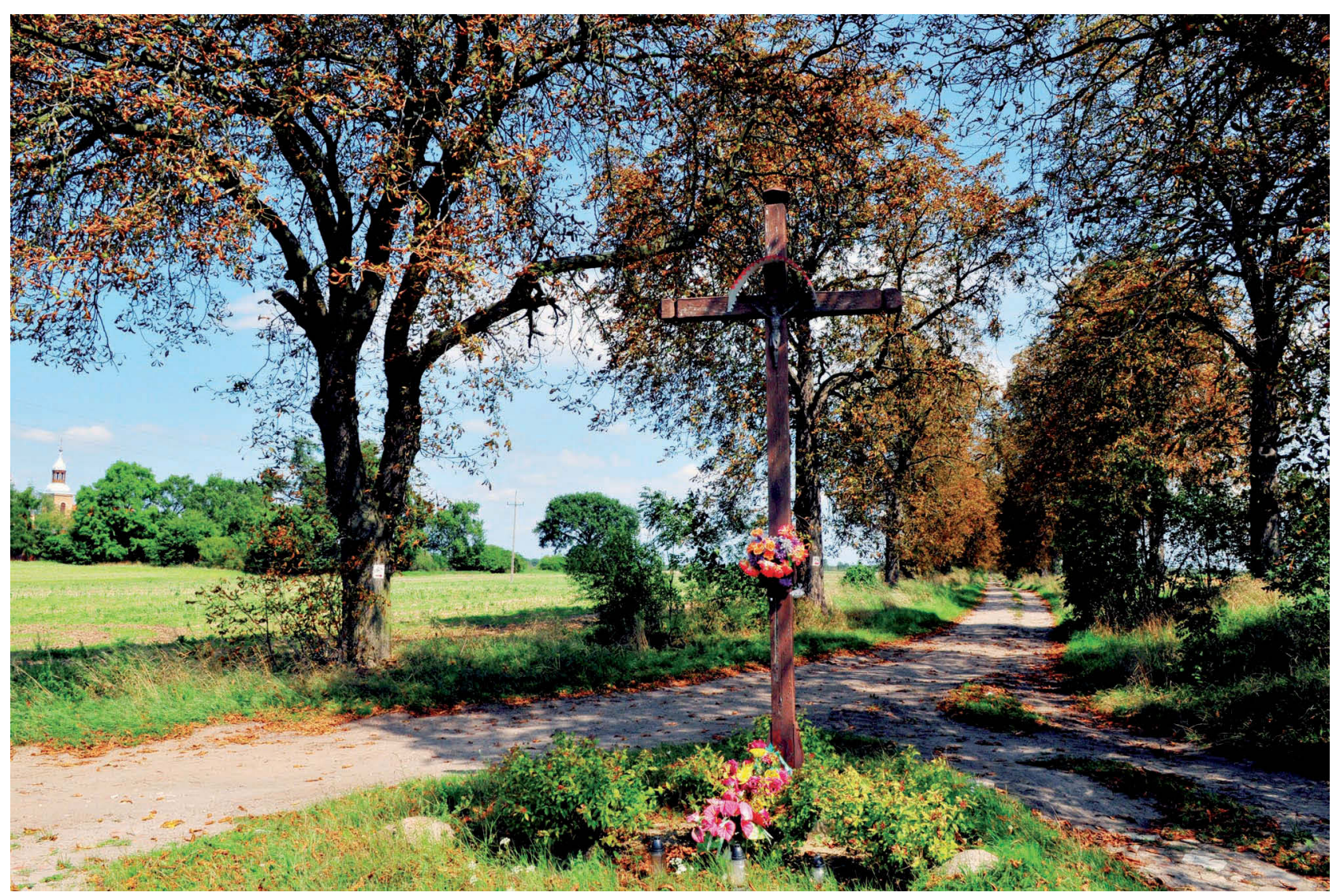

Phot. 9. The avenue of horse chestnuts in Przylepki (Table 2, no. 616, the Brodnica commune); photo M. Krajewski

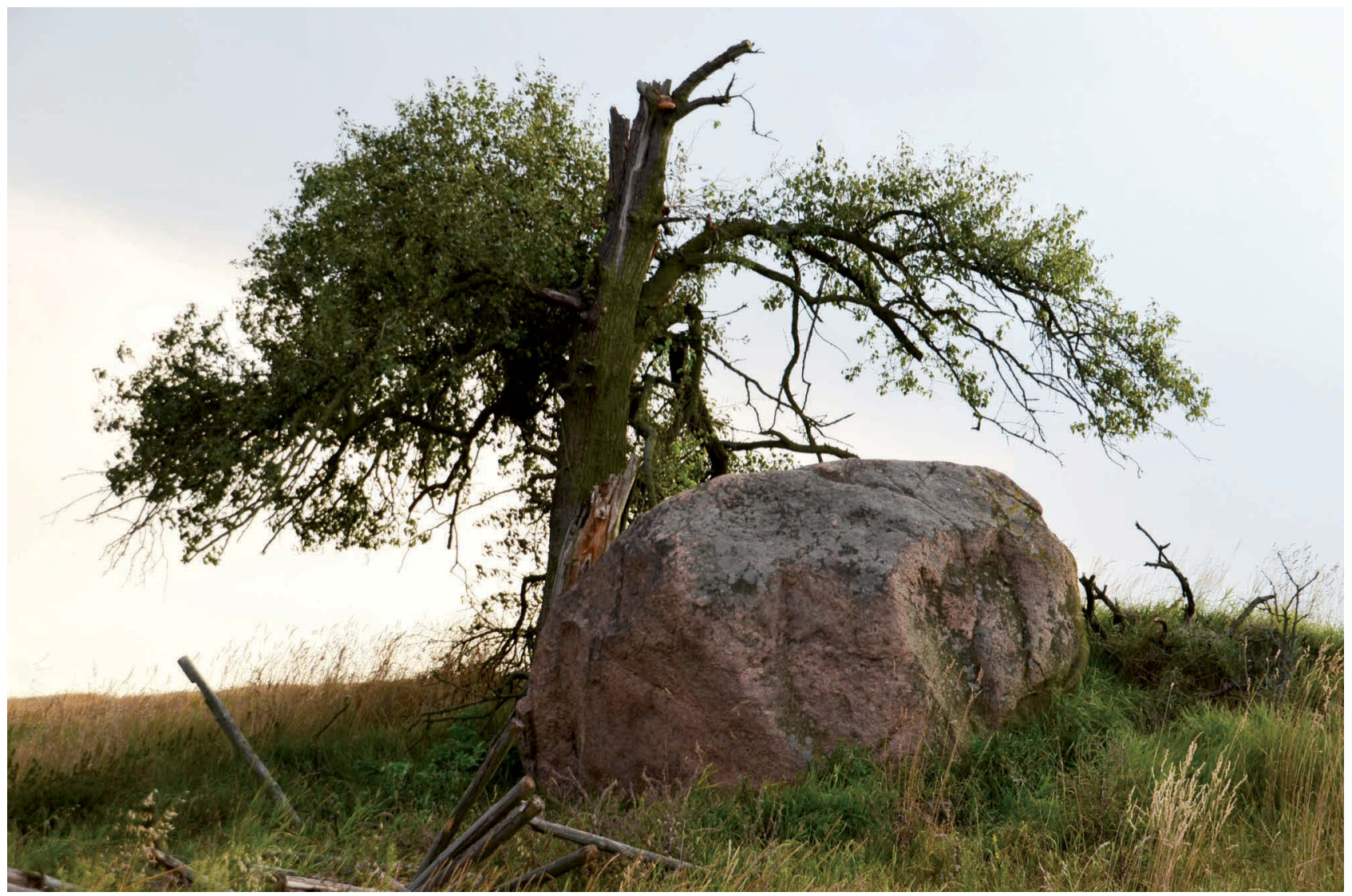

Phot. 10. An erratic from Ostrowieczno (Table 2, no. 104, the Dolsk commune); photo W. Antkowiak 

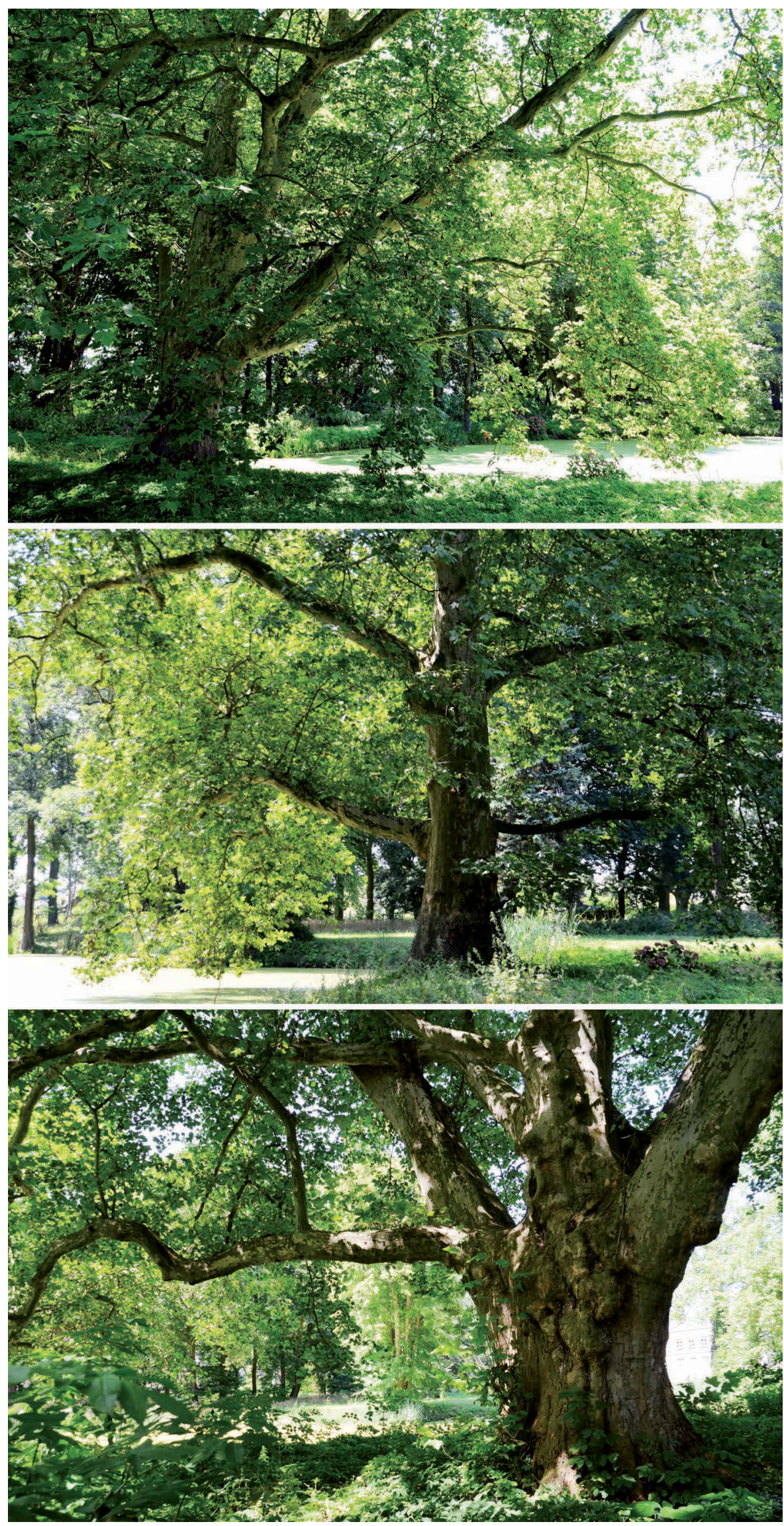

Phot. 11. Planetrees from the former manor park in Szołdry (Table 2, no. 706, the Brodnica commune); photo W. Antkowiak 

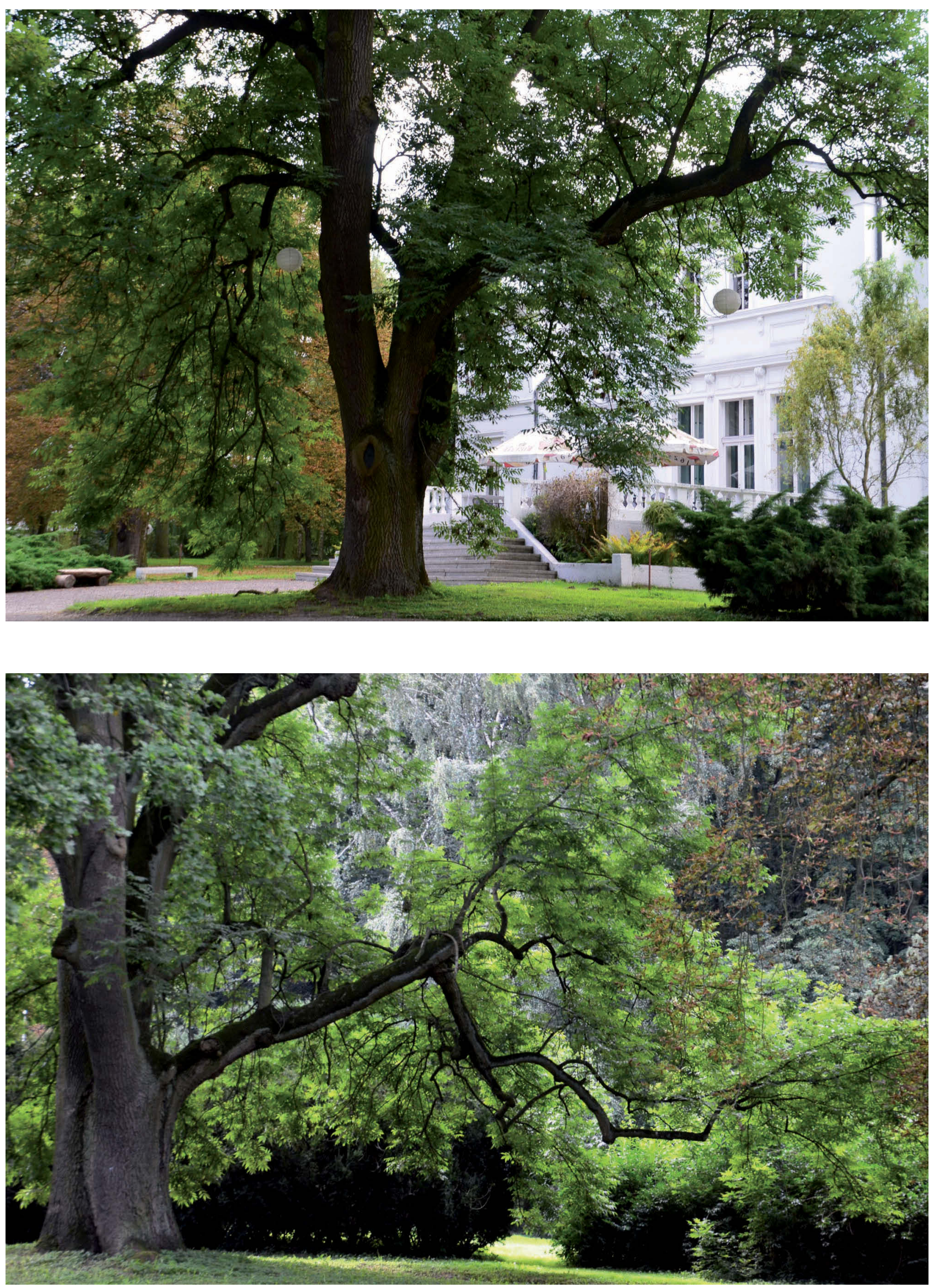

Phot. 12. A tree cluster monument - 2 Fraxinus excelsior trees from the park in Brodnica (Table 2, no. 191, the Brodnica commune); photo W. Antkowiak 
time the monument was registered (1956) the cluster was formed by three English oaks;

- the tree cluster monument no. 539 established in 1986 (the Dolsk commune, Table 2) was composed of five English oaks; at present three trees are left;

- monument no. 770 (the Dolsk commune, Table 2) comprises five English oaks; originally the cluster consisted of six trees;

- the avenue of small-leaved lime trees from Przylepki (the Brodnica commune, Table 2, no. 615) covered by legal protection comprised 272 limes; at present it consists of 265 trees;

- the avenue in the frontal part of the park in the front of the palace in Brodnica (Table 2, no. 663) at the time it was registered as a natural monument comprised 25 horse chestnuts and 12 small-leaved limes; at present it is composed of 21 horse chestnuts and 12 Tilia cordata trees;

- the spruce avenue from Włościejewice (monument no. 812, the Książ Wielkopolski commune, Table 2) in 1994 consisted of 121 Picea abies trees; now it is composed of 98 trees.

The following have to be deleted from the register of natural monuments:

- no. 541 (Podrzekta, the Dolsk commune) - a natural monument established in 1986 to protect two western redcedars Thuja plicata with circumferences of 1.59 and $1.57 \mathrm{~m}$, growing in the former manor park; trees were cut down;

- no. 542 (Rusocin, the Dolsk commune) - natural monument protection was established in 1986 for a white pine Pinus strobus with a circumference of $3.2 \mathrm{~m}$, growing in the former manor park; the tree was cut down;

- natural monument no. 777 (Małachowo, the Dolsk commune) - an erratic (granite pegmatite) covered by legal protection since 1994 was stolen from the roadside along road no. 322;

- no. 93 (the Książ Wielkopolski commune) - a black poplar Populus nigra, growing at the roadside at the section of the road from Włościejewko to Międzyborze, was wind thrown; the stump was extracted.

\section{DISCUSSION AND RESULTS}

The List of trees and shrubs deserving protection in the Poznan region and in Pomerania (Kulesza 1928), A survey of oaks - monuments of nature in Poland (Środoń 1934) and Natural monuments and monuments of nature in the Wielkopolska region (Wodziczko et al. 1938) contain information on objects deserving protection from the period between WWI and WWII.

Kulesza (1928) mentioned two Populus alba trees growing near a road from Chrząstkowo to Dobczyn (the Śrem commune) with circumferences of 8 and 5 $\mathrm{m}$. These huge white poplars were not covered with legal protection as natural monuments. The following were also mentioned: 1. a 600-year old Quercus robur from Luciny with a circumference of $5.05 \mathrm{~m}$, 2. a 500-year old Q. robur from Mechlin (the Śrem commune), 3. a giant English oak from Mszczyn with a circumference of $8.27 \mathrm{~m}$, and 4 . two oaks with circumferences of 6.12 and $6.18 \mathrm{~m}$ from Brześnica. These oaks were not covered with legal protection as natural monuments.

The list of oaks was supplemented by ŚRODOŃ (1934) with two trees from Godurów (the Orliniec forest division) with circumferences of $\pm 10 \mathrm{~m}$ each; these giant trees were not covered with legal protection as natural monuments.

Wodziczko et al. (1938) mentioned other English oaks: 1. an oak from Międzyborze with a circumference of $4.25 \mathrm{~m}, 2$. an oak with a circumference of 4.66 $\mathrm{m}$ growing at the roadside of a road to Jarosławki, 3 . two conjoined oaks from the Mchy forest district, in which arms for insurgents of 1848 were hidden, 4 . several oaks from Lipówka, at the road to Błażejewo and in the neighbouring forests, with circumferences of 5.52, 5.85, 4.04, 5.71 and $5.85 \mathrm{~m}, 5$. two oaks from the Orliniec forest division with circumferences of 6.56 and $6.62 \mathrm{~m}, 6$. an oak from Zakrzewice with a circumference of $3.69 \mathrm{~m}$. These trees were not covered with legal protection as natural monuments.

They also listed: 7. two oaks from Włościejewki with circumferences of 4.66 and $5.2 \mathrm{~m}$ (most probably the above mentioned oaks in 1956 were covered with legal protection as natural monuments (Table 1, the Książ Wielkopolski commune, natural monuments nos. 101 and 102) at present have circumferences of 5.80 and $5.40 \mathrm{~m}$ ), 8. an oak from Brześnica with a circumference of $4.41 \mathrm{~m}$; it may be assumed that this oak is one of the trees from the tree cluster natural monument no. 771 (Table 2, the Dolsk commune).

Wodziczko et al. (1938) also listed:

- an avenue of old spruces leading to a forester's lodge in the village of Włościejewki, which was covered with legal protection as a natural monument in 1994 (Table 2, the Książ Wielkopolski commune, no. 812),

- several old pines and five black poplars with circumferences of $4.68 \mathrm{~m}, 4.67,4.00 \mathrm{~m}, 3.56 \mathrm{~m}$ and $2.98 \mathrm{~m}$ (probably some of those trees comprise natural monument no. 92 (Table 2, the Książ Wielkopolski commune),

- limes from Konarzyce and Błażejewo; the latter had a circumference of $4.73 \mathrm{~m}$. It was probably entered in the register of natural monuments in 1994 as no. 774 (Table 1, the Dolsk commune, circumference $6.10 \mathrm{~m}$ ),

- several hornbeams with circumferences of approx. $2 \mathrm{~m}$, growing in the village of Włościejewki, - a black poplar from the area of Chrząstowo and Dobczyn, 
- a hybrid black poplar growing at the road from Śrem to Czempiń,

- a hazel and a pear tree from Zakrzewice,

- sessile oaks and a pear tree from Gogolewo.

Natural monuments and monuments of nature in the Wielkopolska region (Wodziczko et al. 1938) also contains information on four erratics from the study area. Three of them from the area of Brześnica were entered in the register of natural monuments under nos. 104, 106 and 107 (Table 2, the Dolsk commune).

In the last decades the number of natural monuments in Poland has increased markedly. According to KuRZAC \& KuCHARSKI (1992), in Poland in 1936 over 2000 monumental objects were registered, while in 1960 there were 3723. Between 1960 and 1993 their number increased 4.6-fold (BRZEźNIAK 1995). In that period stagnation was observed in the number of established natural monuments in the years 19651975 and 1980-1985, which according to HARABIN (1996) was caused by a lack of funds for treatment and preservation of trees and the resulting unwillingness to establish new natural monuments. Nationwide a very high number of natural monuments was registered in the years 1980-1990 (BRZEŹNIAK 1995). The significant increase in the natural monuments established after 1992 was considered by HARABIN et al. (1998) to be related with improved legislation, particularly the Act on nature conservation of 1991, which transferred some authority connected with their establishment to commune offices. In the investigated area in the years 1965-1975 0.8\% natural monuments were established, in the period 1980$198513.0 \%$ natural monuments were registered, while a marked increase in the protected objects was observed in the 1980's (31.3\%) and the 1990's (73 natural monuments were established, i.e. $55.7 \%$ registered natural monuments).

The percentage shares of individual groups of natural monuments in the study area differs greatly from the national data. According to the data of the Central Statistical Office of Poland up to 2012 the national register of natural monuments comprised 36,316 natural monuments, including 29996 single trees $(82.6 \%$ all natural monuments), 3,672 tree clusters $(10.1 \%), 728$ avenues $(2.0 \%), 1,057$ erratics $(2.9 \%)$ and 302 rocks and caves $(0.8 \%)$ and 561 other objects $(1.5 \%)$. In the Wielkopolskie province up to 2012 a total of 3,843 natural monuments were established, including 3,182 single trees $(82.8 \%$ all natural monuments), 427 tree clusters (11.1\%), 99 avenues (2.6\%), 97 erratics $(2.5 \%)$ and 38 other objects $(1.0 \%)$.

In the examined communes of the Śrem county the number of natural monuments inventoried in 2012 is as follows: 85 trees $(64.9 \%$ all natural mon- uments), 30 tree clusters (22.9\%), eight avenues $(6.1 \%)$, six erratics $(4.6 \%)$ and two localities of protected vegetation $(1.5 \%)$.

It results from investigations conducted by ZARZYŃSKI (2003) that trees most frequently registered as natural monuments are English oaks and small-leaved limes. The survey showed that trees of these species were registered most often as natural monuments in the Śrem county.

\section{REFERENCES}

BRzEŹNIAK E. (1995): Rozwój sieci pomników przyrody w Polsce w ostatnim 35-leciu. Chrońmy Przyrodę Ojczystą 3: 7-15.

Harabin Z. (1996): Ochrona drzew pomnikowych w Polsce. Komunikaty Dendrologiczne 2 (24): 5-12.

Harabin Z., Krzemkowski J., Wrona A. (1998): O możliwości zwiększenia liczby drzew pomnikowych w Polsce. Komunikaty Dendrologiczne i Ochrona Krajobrazu 25: 45-63.

Kulesza W. (1928): Wykaz drzew i krzewów godnych ochrony w Poznańskiem i na Pomorzu. Ochrona Przyrody, 7: 9-45.

KuRZAC M., KuChaRSKI L. (1992): Pomnikowe drzewa w Polsce Środkowej. Rocznik Dendrologiczny 40: 61-67.

Olaczek R. (1978): Funkcje parków wiejskich. In: V. Mikhajjlov, K. Zabierowski (eds). Ochrona i kształtowanie środowiska przyrodniczego. Vol. 2. PWN, Warszawa.

ORDINANCE of the Minister of the Environment of 9 July 2004 on protected wild plant species (the Journal of Law Dziennik Ustaw of 28 July 2004) on the power of art. 48 of the Act of 16 April 2004 on nature conservation (the Journal of Law Dziennik Ustaw no. 92, item 880).

Pacyniak C., Smólski S. (1973): Drzewa godne uznania za pomniki przyrody oraz stan dotychczasowej ochrony drzew pomnikowych w Polsce. Roczniki Akademii Rolniczej w Poznaniu 67: 41-66.

Pietrzak J. (2010): Problemy ochrony drzew i krzewów pomnikowych w Polsce. Zarządzanie Ochroną Przyrody w Lasach 4: 283-300.

Seneta W., Dolatowski J. (2008): Dendrologia. Wyd. Nauk. PWN, Warszawa.

ŚRODOŃ A. (1934): Inwentarz zabytkowych dębów w Polsce. Ochrona Przyrody 14: 78-110.

Wodziczko A., Krawiec F., Urbański J. (1938). Pomniki przyrody i zabytki przyrody Wielkopolski. Wydawnictwo Okręgowego Komitetu Ochrony Przyrody na Wielkopolskę i Pomorze, Poznań.

ZARZYŃSKI P. (2003): Liczba pomnikowych dębów i lip w Polsce. Rocznik Dendrologiczny 51: 57-60. 